\title{
The genera Muellerina Bassiouni, 1965 and Thaerocythere Hazel, 1967 from the Neogene of Northwest Europe
}

\author{
A. M. WOOD ${ }^{1} \&$ R. C. WHATLEY ${ }^{2}$ \\ ${ }^{1}$ Centre for Quaternary Studies, School of Natural and Environmental Sciences, Coventry University, Priory Street, Coventry CV1 \\ 5FB, UK. \\ ${ }^{2}$ Institute of Earth Studies, University of Wales, Aberystwyth, Dyfed SY23 3DB, UK.
}

\begin{abstract}
Twenty one species of the genera Muellerina and Thaerocythere are considered. Of these, 11 species, including the type species of both genera, have been described previously. Two species are left in open nomenclature due to inadequate numbers but eight are described as new. These species are: Muellerina latimarginata (Speyer, 1863), M. abyssicola (Sars, 1866), $M$. lacunosa (Jones, 1857), $M$. praeabyssicola Uffenorde, 1981, M. parvipunctata Uffenorde, 1981, Thaerocythere crenulata (Sars, 1866), T. hoptonensis (Brady, Crosskey \& Robertson, 1874), T. mayburyae Cronin, 1991, T. oedichilus (Brady, 1878), T. trachypora (Jones, 1857), T. trapezia (Brady, 1878), and the new species $M$. dolabrata, $M$. metabyssicola, $M$. orygyma, $M$. pliocenica, $T$. biformis, $T$. praecrenulata, $T$. vermiculata, $T$. woutersi and $T$. wittei. The phyletic relationships of these northwestern European species are considered. $J$. Micropalaeontol. 16(1): 1-18, May, 1997.
\end{abstract}

\section{INTRODUCTION}

The type material of Jones $(1857,1870)$, Jones \& Sherborn (1887, 1889), Brady, Crosskey \& Robertson (1874) and Horne \& Kerr (1989), which are presently deposited at the British (Natural History) and Hancock museums, have recently been re-examined. In the light of a recent study by Liebau (1991) and the subsequent re-examination of northwestern European Muellerina and Thaerocythere species, the present authors have attempted to unravel both the taxonomic and evolutionary problems that presently surround the Plio-Pleistocene species of these genera. The biostratigraphical and ecostratigraphical implications arising from this will be published elsewhere (Wood $\&$ Whatley, in press; Wilkinson et al., in press).

\section{PREVIOUS WORK}

The most significant contributions, in the context of the present study, are undoubtediy those of Wouters (1979), Uffenorde (1980-1990), Liebau (1991) and Cronin (1991). The investigation of adductor muscle scar patterns and carapace characteristics of Muellerina by Wouters (1979) suggested a tendency towards subdivision within the former and changes in the outline and ornamentation of the valves. He suggested that a gradual change in the composition (grouping sensu Wouters, 1979 , p. 225) of the muscle scars could be seen through time. However, the evolution of the muellerinids within the southern North Sea basin was justly considered by Uffenorde (1986) to be much more complicated and not just a simple case of muscle scar subdivision or the abatement of reticulation (Uffenorde, 1980, 1986). Investigations into the phylogentical behaviour of sculptural components (macrorecticulation) in Tertiary to Recent trachylebrids and hemicytherids (Liebau, 1977, 1978, 1991) has led to the taxonomical revision of 'Quadracythere-like hemicytherids' in which Liebau (1991) erected a number of new Thaerocythere subgenera and species. Similarly, Cronin (1991) has described a number of new Muellerina and Thaerocythere species from the Pliocene/Pleistocene of Tjörnes, Iceland.

\section{LITHOSTRATIGRAPHY, BIOSTRATIGRAPHY AND BIO- CHRONOLOGY OF NORTHWESTERN EUROPEAN NEO- GENE DEPOSITS}

The lithostratigraphical, biostratigraphical and biochronolgical framework for the British and Dutch Neogene successions have recently been reviewed by Wood et al. (1994). In the same paper, a number of new ostracod-based ecozones were erected on the basis of palaeoclimatic-related changes in the generic composition of Upper Miocene and Pliocene ostracod assemblages. The extent of this new ecozonation and previous foraminiferal and palynological biostratigraphical schemes are presented in Figs 1 and 2.

\section{MATERIAL}

Four Dutch Geological Survey boreholes, Altena VI 49E83, Nieuwkuik 45C190, Klundert 43H63 and Cuyck 46A147, comprising comparative sections of the Breda and Oosterhout formations, were examined for ostracods. Figure 3 shows the location of the boreholes in relation to the disposition of major structures within the Netherlands. The sampling intervals and lithologies of Dutch boreholes $43 \mathrm{H} 63$ and 46A147 are presented in Fig. 4.

Marine ostracod assemblages from three East Anglian formations were analysed: the Coralline Crag Formation at Sutton Knoll (TM 304440) and Raydon Hall (TM 43265017 British Geological Survey borehole), the Red Crag Formation at Walton Cliff (TM 26732352), Buckanaye Farm (TM 356424) and Neutral Farm (TM 372811) and the Norwich Crag Formation (Chillesford Sand Member) at Chillesford Church Pit (TM 38285230). The regional disposition of sampled localities and specific sampling horizons are given in Figs 5 and 6.

\section{SYSTEMATIC DESCRIPTIONS}

List of abbreviations: ALV-F = Adult left valve, female; ARV$M=$ Adult right valve, male; $A C p=$ Adult carapace; $A-n=$ 
Wood \& Whatley
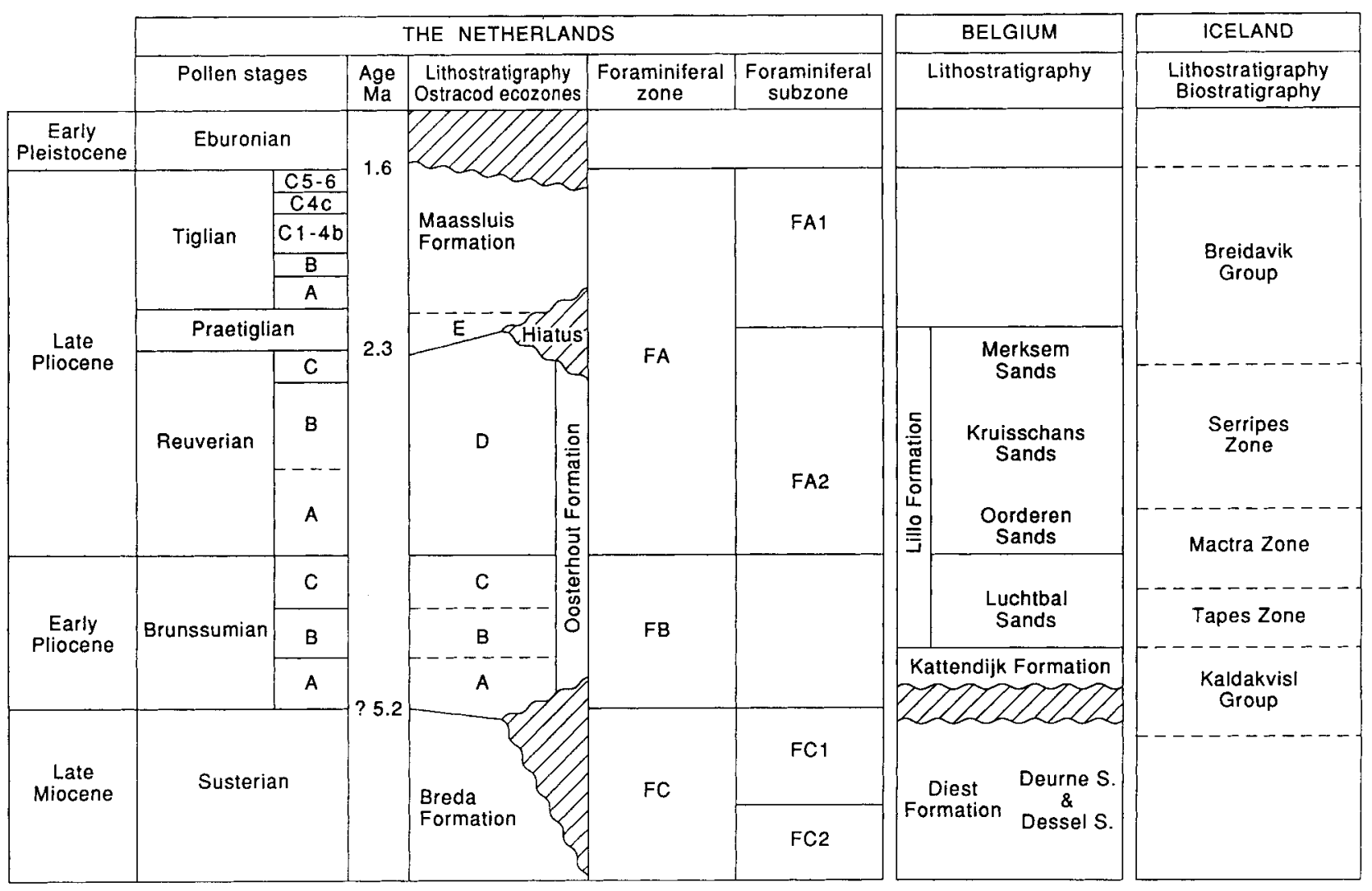

Fig. 1. Lithostratigraphy and biostratigraphy of the Dutch, Belgium and Icelandic Neogene successions (adapted after Wood et al., 1994).

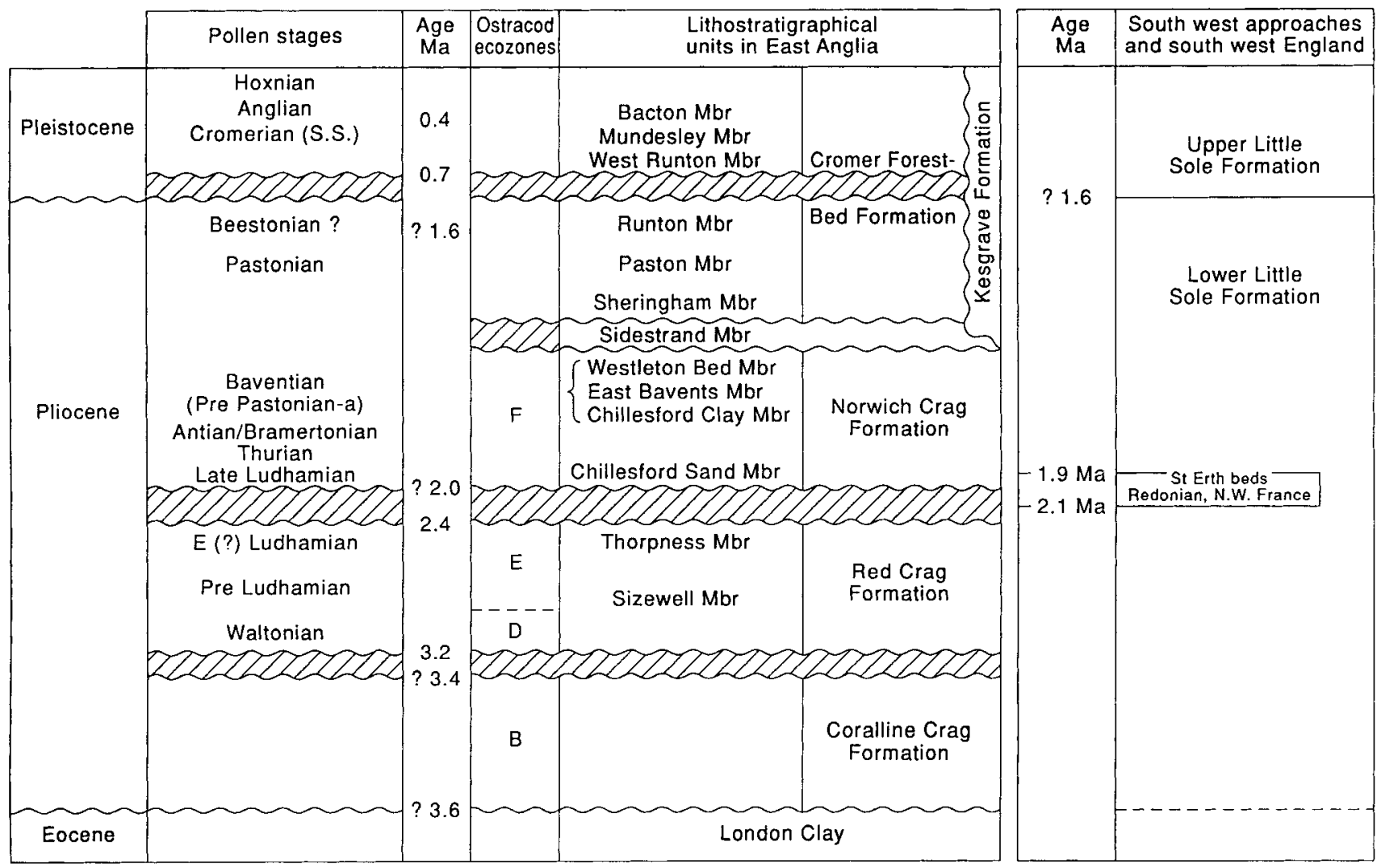

Fig. 2. Lithostratigraphy and biostratigraphy of the East Anglian Pliocene succession (adapted after Wood et al., 1994). 


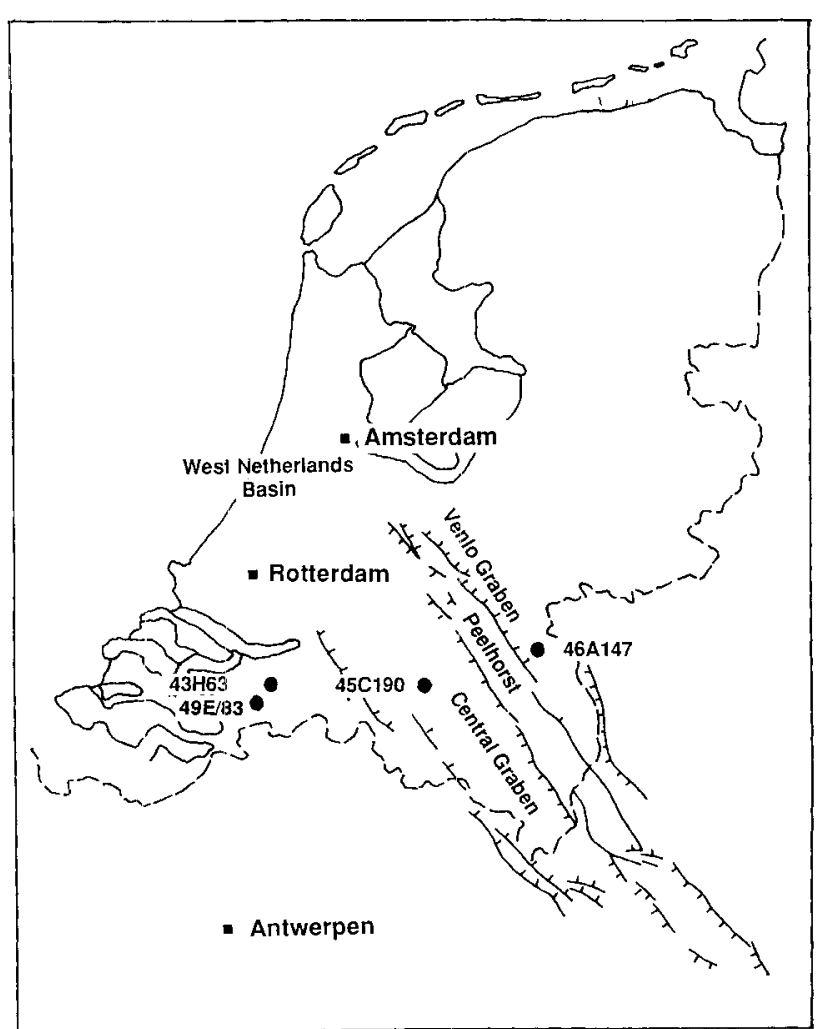

Fig. 3. Location of the four Dutch boreholes under investigation and their relationship to major structural feature (after Wood et al., 1994).

juvenile stage. Type material is either deposited in the Department of Palaeontology, Natural History Museum or the British Geological Survey, for which the catalogue number prefixes are OS and MPK, respectively. Other material is deposited in the Adrian Wood collection in the Micropalaeontology Museum, Institute of Earth Studies, Aberystwyth with catalogues numbers AMW/PL/0 no.

Class Ostracoda Latrielle, 1806 Order Podocopida Müller, 1894

Suborder Podocopida Sars, 1866

Superfamily Cytheracea Baird, 1850

Family Hemicytheridae Puri, 1953

Subfamily Hemicytherinae Puri, 1953

Genus Muellerina Bassiouni, 1965

Type species. Cythere latimarginata Speyer, 1863.

Emend. Diagnosis. Carapace subovate to elongate/subquadrate, with thick, generally smooth, marginal rims imparting a truncated aspect to the end margins in dorsal view. Anterior and posterior margins may be denticulated. Dorsal and ventral margins converging posteriorly. Upper part of posterior margin straight or weakly concave, lower part convex, together forming weak posteroverntral caudal process. Dimorphic, males proportionally more elongate, less inflated in dorsal view. Ornament pitted/reticulate with a single concentric row of fossae inside the marginal rim and subcentral tubercle. Maximum length below mid height, greatest height at or just anterior of anterior cardinal angle, maximum width at sub-central tubercle.
Row of four adductor muscle scars, middle two may be subdivided; two frontal scars, ventral scar may be bilobate. Hinge holamphidont with short thick teeth. Narrow anterior and posterior vestibula may be present; marginal pore canals sinuous/straight, simple, 20-30 anteriorly; 10-14 posteriorly.

Remarks. The re-examination of adductor muscle scar patterns in Muellerina, using a quite separate database of Upper Miocene to Recent species from northwestern Europe, clearly supports the original conclusions of Wouters (1979). Using composite counts for muscle scar groups $1 / 2$ and $3 / 4$ our results confirm the progressive division of median scars from the Miocene to the Recent. The adductor muscle scar pattern of 200 adult specimens, belonging to six species, were analysed from Neogene sites in France, England and The Netherlands. The relative percentage of the three adductor muscle scar groupings, through time, are represented in Fig. 7.

\section{Muellerina latimarginata (Speyer, 1863)}

(Pl. 1, fig. 1)

1863 Cythere latimarginata Speyer: 22, p1. 3, figs 3a-e.

non 1874 Cythere latimarginata Speyer; Brady, Crosskey \& Robertson: 163, pl. 16, fig. 6 (=Cythere abyssicola G.O. Sars, 1865).

1918 Cythereis latimarginata (Speyer); Kuiper: 41, pl. 2, fig. 14. 1965 Muellerina latimarginata (Speyer); Bassiouni: 510, pl. 1, figs $2 \mathrm{a}-\mathrm{c}$.

1981 Muellerina latimarginata latimarginata (Speyer); Uffenorde: 161 , pl. 3, figs $7 \& 10$; pl. 7, fig. 4 .

Diagnosis. Carapace small, subrectangular, symmetrical about median line. Anterior broadly rounded, posterior somewhat truncated. Surface with moderately large pits/fossae and two delicate ribs. The first parallel to the ventral margins, terminating in a weak posteroventral swelling, the second is angled from the subcentral tubercle towards the posterior cardinal angle. In dorsal view carapace is tapered in front of posterior marginal rim. Ventral frontal muscle scar is often bilobate.

Material. East Anglia, 2V; The Netherlands, 3 CP, $11 \mathrm{~V}$. Dimensions.

$\begin{array}{lllcc} & \text { Cat. No. } & \text { Site } & \text { Length } & \text { Height } \\ \text { ALV-F } & \text { AMW/PL/016 } & 43 \mathrm{H} / 63(175) & 0.70 & 0.31 \\ \text { RV ?A-3 } & \text { AMW/PL/017 } & 43 \mathrm{H} / 63(176) & 0.50 & 0.18\end{array}$

Distribution. Upper Oligocene of North West Germany (Uffenorde, 1981) and Belgium (Kuiper, 1918). Most common in the Miocene of Belgium, Germany and the Netherlands (Wouters, 1979). Rare in the Lower Pliocene of the Netherlands (FB benthonic foraminifera zone, see Doppert, 1975, 1980) and the Coralline Crag Formation of East Anglia, England.

Remarks. Jones \& Sherborn (1887) described a single specimen of Muellerina latimarginata from the Coralline Crag Formation at Sutton Knoll (TM 304 440). It appears, however, that this specimen is now missing from the collections of the Natural History Museum.

\section{Muellerina abyssicola (Sars, 1866)}

(P1. 1, figs 2 \& 3)

1866 Cythereis abyssicola sp. nov. Sars: 43.

1874 Cythere latimarginata Speyer; Brady, Crosskey \& Robertson: 163, pl. 16, fig. 6 (non Speyer, 1863). 


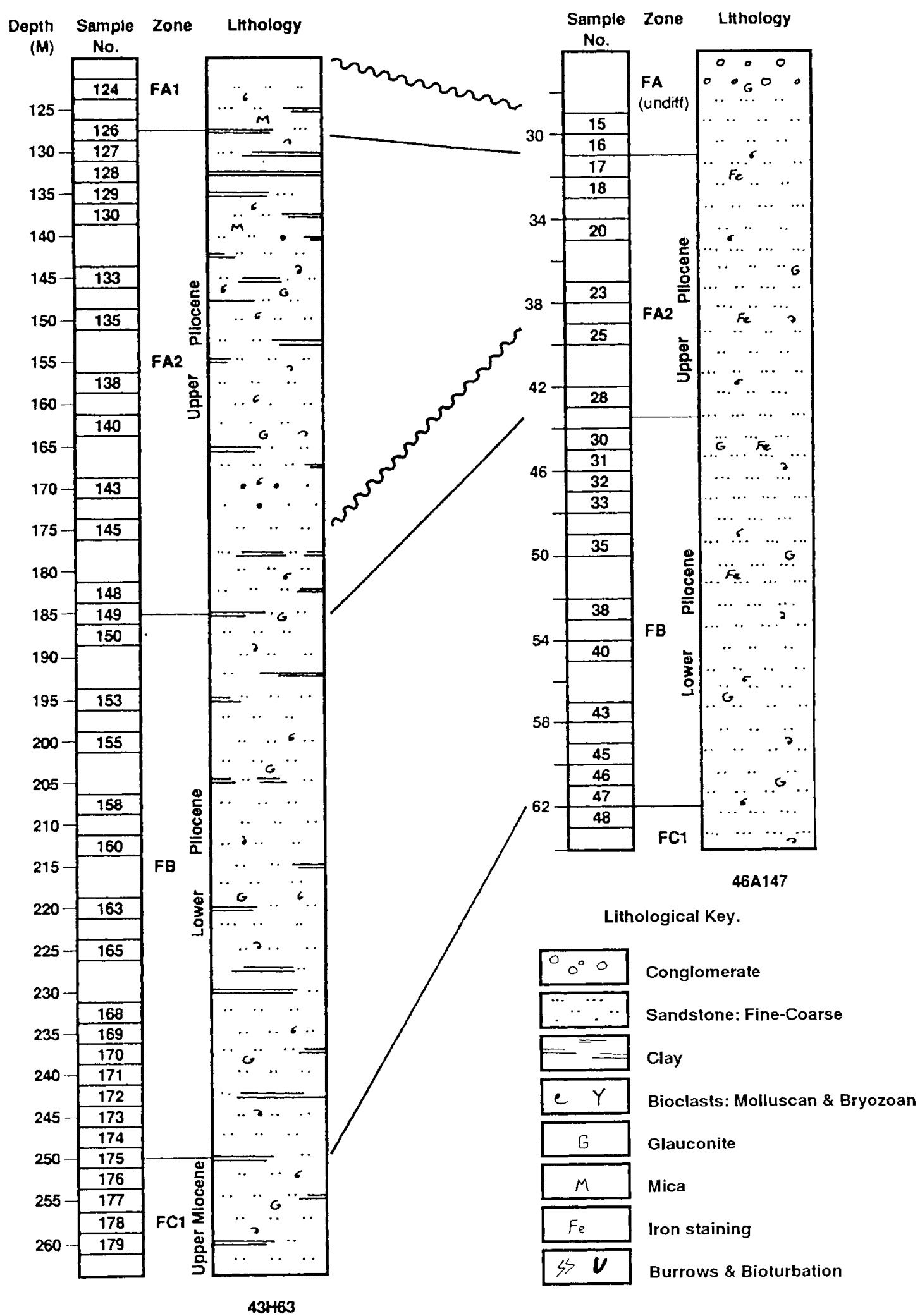

Fig. 4. Lithology and sampled horizons of the Dutch boreholes Klundert 43 H63 and Cucyk 46A147. 


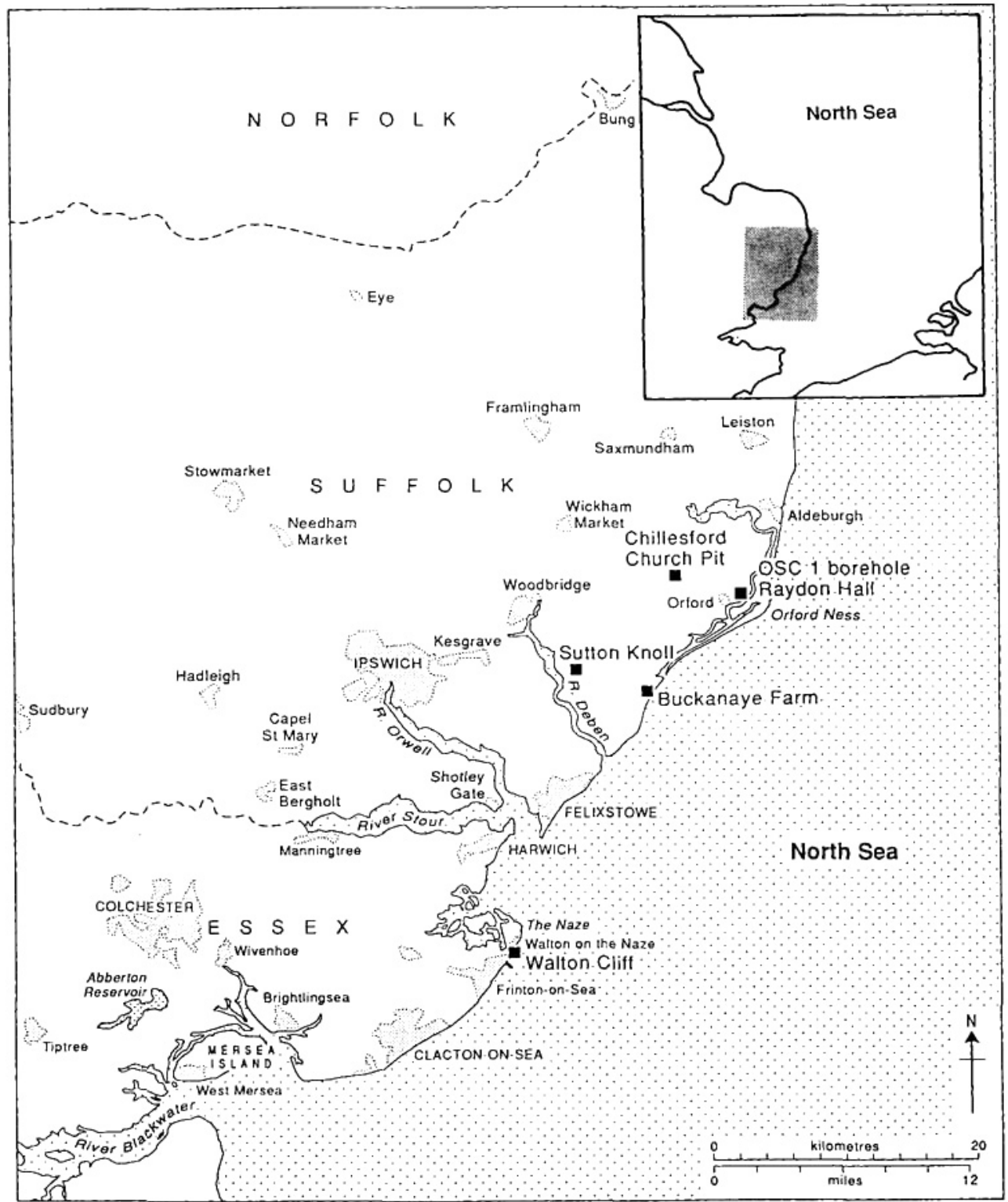

Fig. 5. East Anglian Pliocene sites under investigation.

1965 Muellerina abyssicola (Sars); Bassiouni: 510, pl. 1, figs 3-6. 1969 Murrayina latimarginata (Speyer); Yassini: 84, pl. 24, fig. 5; pl. 39, figs 15 \& 16 (non Speyer, 1863).

Diagnosis (adapted after Athersuch et al., 1989). Carapace subovate; dorsal and ventral margins slightly sinuous, anterior and posterior margins rounded. Marginal rims very broad. Ornament coarsely pitted/reticulated, quadrate fossae inside the marginal rim, and rounded to subquadrate fossae elsewhere.

Material. In excess of 2000 specimens.

Dimensions.

$\begin{array}{llllc} & \text { Cat. No. } & \text { Site } & \text { Length } & \text { Height } \\ \text { ALV-F } & \text { AMW/PL/018 } & 1962,160(8) & 0.78 & 0.45 \\ \text { ARV-M } & \text { AMW/PL/019 } & 1962,160(10) & 0.76 & 0.40\end{array}$

Remarks. Although both carapace shape and disposition of fossae are quite dissimilar, $M$. abyssicola (Sars) was commonly placed in synonymy with $M$. latimarginata (Speyer) by 19 th century authors. However, comparisons with its proposed Pliocene ancestor Muellerina metabyssicola sp. nov. reveal that a number of ornamental features have been retained. These include the posteromedian plication connecting posterodorsal and subcentral tubercles which, although not as salient as in $M$. metabyssicola $\mathrm{sp}$. nov. is very obvious. The mid-dorsally positioned compressed ' $S$ ' shaped node-ridge-node structure is also retained. In dorsal view, both species are listricly truncated submarginally at the posterior.

Distribution. $M$. abyssicola has been recorded from the Pleistocene (Devensian) of southwest Norway (Lord, 1980), Bay of Biscay (Yassini, 1969; Peypouquet, 1971) and the Hoxnian of Denmark and northern Germany (Bassiouni, 1965). Its present distribution on the northeast Atlantic shelf, as recorded by Wood \& Whatley (1994), is from the Bay of Biscay north to the Barents Sea. 

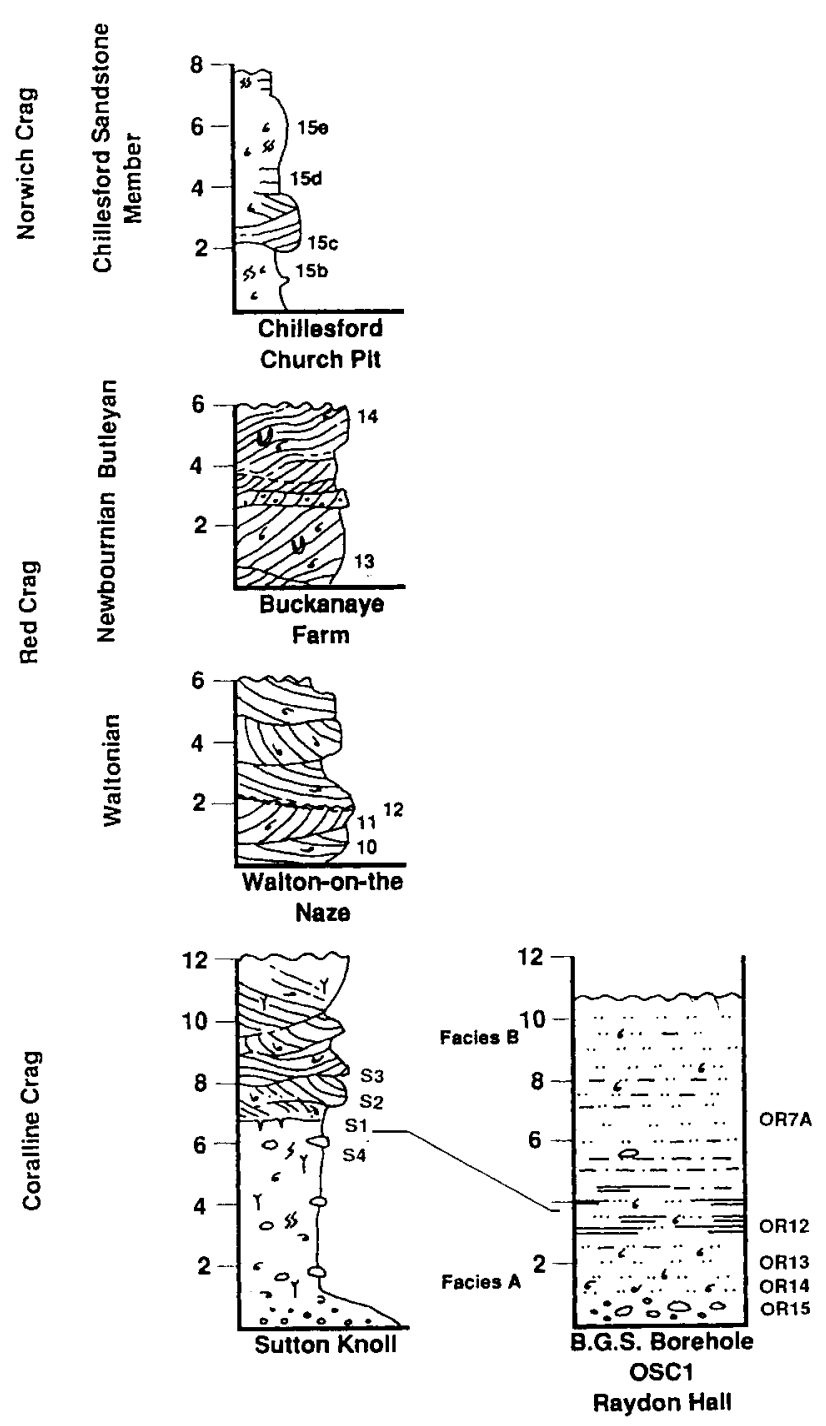

Fig. 6. Lithology and sampled horizons of East Anglian Pliocene sites (adapted after Wood et al., 1992).

\section{Muellerina lacunosa (Jones, 1857)}

$$
\text { (P1. 1, figs 4-6) }
$$

1857 Cythere lacunosa Jones: 31, pl. 3, figs 5a-b

1870 Cythere sublacunosa Jones; 156 (nom. nov. pro Cythere lacunosa Jones, 1857; non Cytherina lacunosa Reuss, 1850).

1889 Cythere sublacunosa Jones \& Sherborn; 27.

1979 Muellerina lacunosa (Jones); Wouters: 228-229, pl. 2, fig. $2 \mathrm{~b}$ (non $\mathrm{pl}$. 2, figs $2 \mathrm{a} \& 2 \mathrm{c}=$ Muellerina orygyma sp. nov.).

1980 Murrayina lacunosa (Jones); Wilkinson: pl. 2, fig. 14 (non pl. 2, fig. $12=$ Muellerina pliocenica sp. nov.).

non 1989 Muellerina lacunosa (Jones); Horne \& Kerr, pl. 2, fig. d (= Muellerina pliocenica sp. nov.).

Diagnosis. A species of Muellerina with numerous, though rarely coalesced, subcircular fossae set within an undulose network of muri, concentrically arranged around a well developed sub- central tubercle. Weakly developed posteroventral and posterodorsal tubercles. Indistinct, plicate, ridge runs from the subcentral tubercle posterodorsally. In dorsal view, convex to straight truncation submarginal to the posterior. Marginal radial pore canals numerous, $14-16$ anteriorly, 46 posteriorly, straight/sinuous.

Material. East Anglia, 19CP, 160V; the Netherlands, 5CP, $115 \mathrm{~V}$. Dimensions.

$\begin{array}{lllll} & \text { Cat. No. } & \text { Site } & \text { Length } & \text { Height } \\ \text { ALV-F } & \text { AMW/PL/020 } & \text { OSC1 OR7a } & 0.76 & 0.4 \\ \text { ARV-M } & \text { AMW/PL/021 } & \text { OSC1 OR12 } & 0.89 & 0.44 \\ \text { ALV-M } & \text { AMW/PL/022 } & \text { OSC1 OR12 } & 0.84 & 0.45 \\ \text { ARV-F } & \text { AMW/PL/023 } & \text { OSC1 OR15 } & 0.81 & 0.45\end{array}$

Distribution. Pliocene; Kattendijk and Lillo formations, Belgium; FB zone (Doppert, 1980) of the Oosterhout Formation, Holland; Coralline Crag Formation, Waltonian, Butleyan and Newbournian stages of the Red Crag Formation, East Anglia, UK.

Remarks. Muellerina lacunosa (Jones) bears a strong resemblance to its nominated ancestor $M$. parvipunctata Uffenorde (1981) and also to Muellerina orygyma sp. nov. However, $M$. lacunosa can be easily distinguished from $M$. orygyma sp. nov. as the ornament of the former is constructed from a dense network of large fossae and also comprises two posterior tubercles. $M$. parvipunctata although similar in outline has an ornament dominated by a strong, posteriorly bifurcate, ventromarginal ridge and rather small cellate fossae.

Muellerina parvipunctata Uffenorde, 1981

Distribution. Upper Miocene; Reinbekium and Gramium of northwest Germany.

Remarks. This species is similar in outline to $M$. lacunosa (see remarks) but appears to be restricted both stratigraphically and geographically to the Upper Miocene of northwest Germany where it can occur with both $M$. praeabyssicola Uffenorde, 1981 and Muellerina latimarginata morphotype 1 Uffenorde (1981, p. 165).

Muellerina praeabyssicola Uffenorde, 1981

Distribution. Upper Miocene of northern Germany.

Remarks. The earliest species of the $M$. praeabyssicola-M. metabyssicola $-M$. abyssicola lineage, restricted to the Upper Miocene of Germany. $M$. praeabyssicola can be distinguished from $M$. metabyssicola as the latter is compressed and possesses two conspicuous mediodorsal tubercles, however, both possess the shallow 'S'-shape plication in the dorsomedian region.

\section{Muellerina dolabrata sp. nov.}

(Pl. 1, figs 10 \& 11)

Derivation of name. Latin, dolabratus $=$ shaped like an axe. With reference to the 'axe head' shape of the carapace in lateral view. Diagnosis. A species characterized by its axe head shaped carapace in lateral view. Almost symmetrical about the median height line. Anterior marginal reticulate with fine radial ridges. Reticulation composed of 15-18 large, circular/subovate, occasionally linked, cellate fossae with normal pores proximal to muri. Additional, scattered normal pores, common. Posterodorsal and posteroventral tubercles present, the latter more strongly so. 


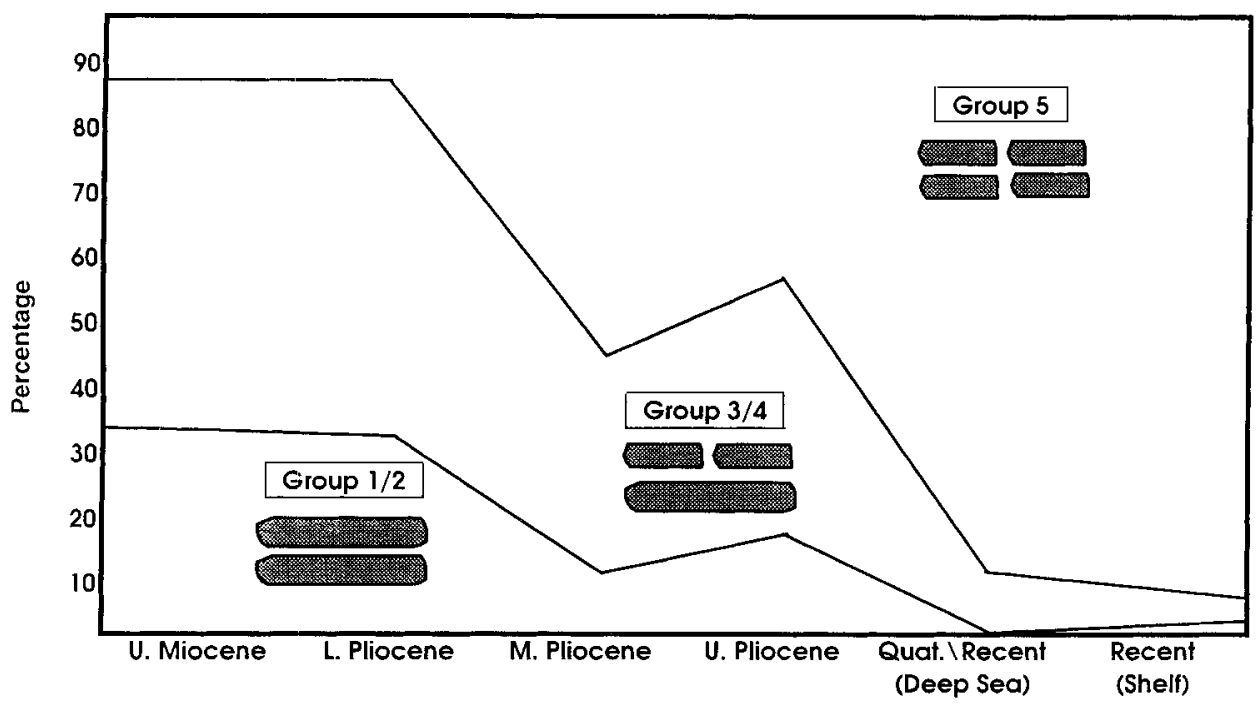

Fig. 7. Percentage variations in muellerinid adductor muscle scar groups (after Wouters, 1979) from the Upper Miocene to Recent of northwestern Europe.

Type locality and horizon. Coralline Crag Formation, BGS. borehole OSC1: sample level OR7a, near Orford, Suffolk, East Anglia, UK.

Material. East Anglia, 11CP, 15V; the Netherlands, 11CP, $80 \mathrm{~V}$. Dimensions of types.

$\begin{array}{lllcr} & \text { Cat. No. } & \text { Site } & \text { Length } & \text { Height } \\ \text { Holotype ARV-F } & \text { MPK9768 } & \text { OSC1 OR7a } & 0.67 & 0.37 \\ \text { Paratype ALV-F } & \text { MPK9769 } & \text { OSC1 OR14 } & 0.65 & 0.37 \\ \text { Paratype ALV-M } & \text { MPK9770 } & \text { OSC1 OR14 } & 0.63 & 0.36 \\ \text { Paratype ARV-M } & \text { MPK9771 } & \text { OSC1 OR14 } & 0.62 & 0.33\end{array}$

Distribution. Upper Miocene; FCl zone and Lower Pliocene FB zone Oosterhout Formation, the Netherlands. Pliocene; Coralline Crag Formation, Sutton Knoll and BGS borehole OSC1, Orford, Suffolk, UK.

Description. Carapace subquadrate, dorsal margin convex, ventral sinuous. Anterior margin broadly round, posterior somewhat truncated. In dorsal view the outline is sinuous but truncated in front of the posterior marginal rim. Maximum length well below mid height. Eye tubercles conical, more weakly developed in males. Anterior rim possesses four to seven fine, transverse, arcuate/sinuous riblets. Ornament consists of 15-17 subcircular/ovate cellate fossae, occasionally linked below a sturdy subcentral tubercle. Single, delicate, rib angled from the posteromedian region to the subcentral tubercle. Sensillum pores simple, small, intermural or peripheral on the solum. Avestibulate, inner lamalla broad, marginal pore canals simple straight, 24-26 anteriorly, nine posteriorly, 17 orally.

Remarks. $M$. dolabratus $\mathrm{sp}$. nov. possessing a number of features common to $M$. praeabyssicola Uffenorde, 1981, i.e. concave dorsal margin with raised anterior cardinal angle, fine anterodorsal carinae, angular/listric truncation of the posterior region and two posterior tubercles.

Muellerina metabyssicola sp. nov.

(Pl. 1, figs 10 \& 11)

Derivation of name. Greek; meta = between. Pertaining to the intermediate evolutionary stage of this species within the $M$. praeabyssicola Uffenorde-M. abyssicola (Sars) lineage.

Diagnosis. Carapace elongate, subquadrate/trapeziform. Dorsal margin concave with prominent raised anterior cardinal angle, ventral concave. Listric truncation of posterior in dorsal view. Conspicuous subcentral, posterodorsal and posteroventral tubercles. Two further tubercles positioned in the dorsomedian and posteromedian regions connected by a conspicuous, sinuous, carinate ridge. Second, finer, carina connecting subcentral and posterodorsal tubercles.

Type locality and horizon. Coralline Crag Formation, BGS borehole OSC1: OR7a, near Orford, Suffolk, East Anglia, UK. Material. East Anglia, 19V; the Netherlands, 5CP, 14V.

\section{Dimensions of types.}

$\begin{array}{llllc}\text { Cat. No. } & \text { Site } & \text { Length } & \text { Height } \\ \text { MPK9772 } & \text { OSC1 OR7a } & 0.77 & 0.41 \\ \text { MPK9773 } & \text { OSC1 OR15 } & 0.68 & 0.37\end{array}$

$\begin{array}{lllll}\text { Holotype ARV-F } & \text { MPK9772 } & \text { OSC1 OR7a } & 0.77 & 0.41 \\ \text { Paratype LV A-1 } & \text { MPK9773 } & \text { OSC1 OR15 } & 0.68 & 0.37\end{array}$

Distribution. Lower Pliocene; FB zone, Oosterhout Formation, the Netherlands; mid-Pliocene; Coralline Crag Formation, Orford and Sutton Knoll, East Anglia, UK.

Description. Carapace elongate subquadrate/ovate to trapeziform. Dorsal margin of LV concave, raised anterior cardinal angle, RV sinuous. Ventral margin, in both $L V$ and $R V$, convex. Anterior margin rounded. In dorsal view, posterior listrically truncated. Maximum length just below the mid height. Margin rims broad, rounded in dorsal view. Conspicuous eye tubercle situated just beneath anterior cardinal angle. Coarsely reticulate with rounded/subovate fossae, quadrate submarginally. Fossae and muri suppressed with respect to marginal reticulum. Plicate ventromarginal ridge terminates in the posteroventral region in the form of an alate swelling. Posterodorsal tubercle more weakly developed. Arcuate, ridge, forming an inter-connection between tubercles situated behind mid-point on the dorsal margin and below the anterior cardinal angle. Avestibulate, moderately broad inner lamalla, marginal pore canals, straight, numerous; 24 anteriorly, 11 orally and nine posteriorly.

Remarks. Although much larger, both the outline of the carapace and the disposition of reticulation of this species are 


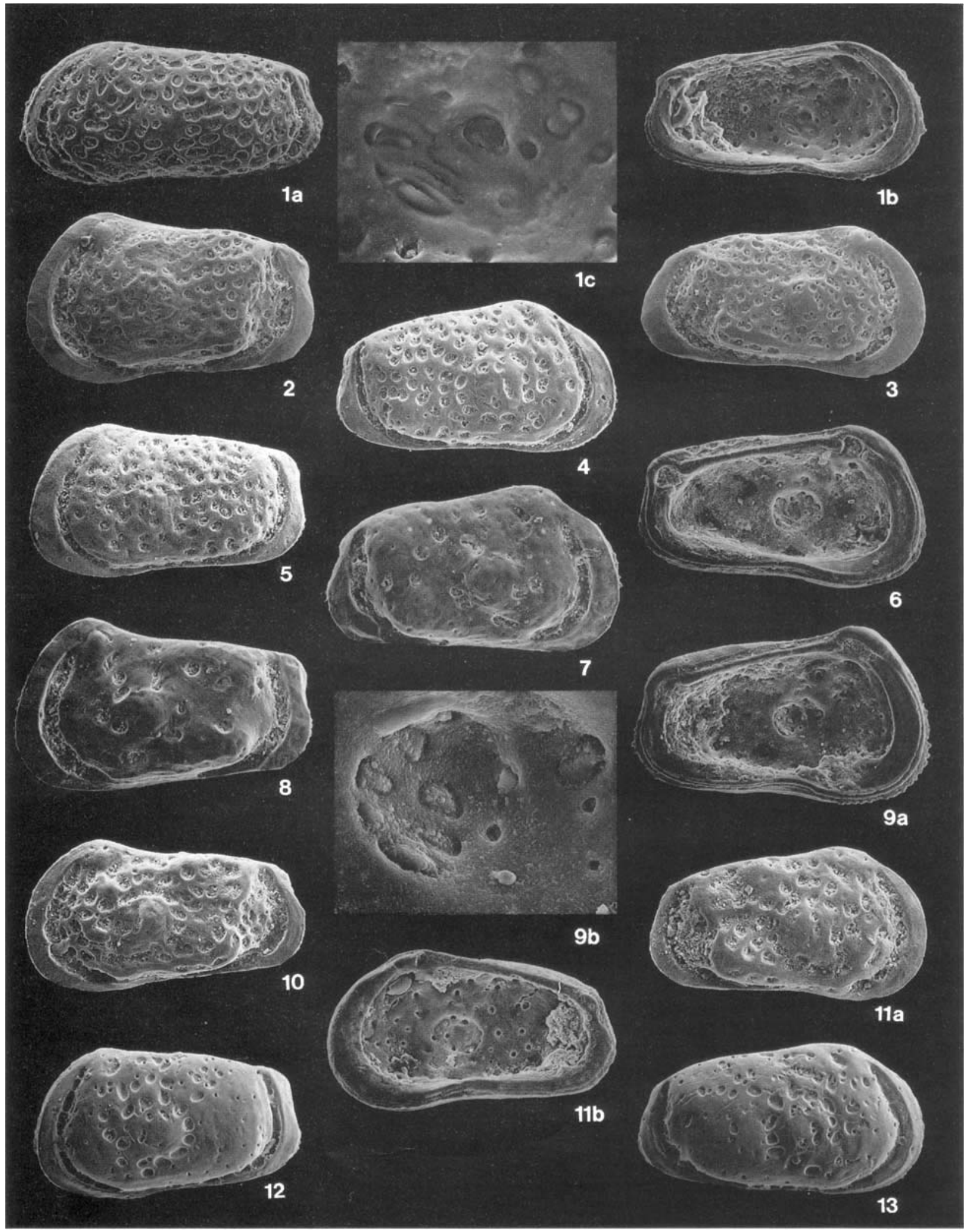

Plate 1 
similar to those of $M$. praeabysicola and $M$. abyssicola. However, the posterior tubercles of $M$. praeabyssicola are greatly inflated and dorsomedian swellings weaker. Although retaining the 'S'-shaped dorsomedian structure in the form of an insubstantial, raised, murus; the ornament of $M$. abyssicola is conservative by comparison.

A fourth species, described by C. A. Maybury (pers. comm.) from the Redonian (Upper Pliocene) of northwest France, may also be a member of the 'abyssicola' lineage.

Muellerina orygyma sp. nov.

(Pl. 1, figs 12 \& 13; Pl. 2, fig. 1)

?1878 Cythere latimarginata Speyer; Brady: 389-390, pl. 64, figs 8a-d (non Speyer, 1863).

1979 Muellerina lacunosa (Jones); Wouters: 228-229, pl. 2, figs $2 \mathrm{a}$ and $2 \mathrm{c}$ (non Jones, 1857) (non pl. 2, fig. $2 \mathrm{~b}=$ Muellerina lacunosa (Jones)).

Derivation of name. Greek; orygymus = moat-like trench. Pertaining to the ring of fossae encircling the raised subcentral tubercle.

Diagnosis. A species of Muellerina with a well developed pattern of open reticulation characterized by a concentration of fossae anterodorsally and in a chain around the central tubercle. Numerous, small simple pores. Inflated in front of the posterior marginal rim.

Type locality. Klundert $43 \mathrm{H} / 63$ borehole, $256.50-259 \mathrm{~m}$; FCl zone, Oosterhout Formation, Upper Miocene, the Netherlands. Material. The Netherlands, 21CP, 361V.

Dimensions of types.

$\begin{array}{llllr} & \text { Cat. No. } & \text { Site } & \text { Length } & \text { Height } \\ \text { Holotype ALV-F } & \text { OS14185 } & 43 \mathrm{H} / 63(178) & 0.75 & 0.43 \\ \text { Paratype ARV-F } & \text { OS } 14186 & 43 \mathrm{H} / 63(178) & 0.78 & 0.42 \\ \text { Paratype ALV-M } & \text { OS14187 } & 43 \mathrm{H} / 63(177) & 0.75 & 0.41 \\ \text { Paratype A.RV-M } & \text { OS14188 } & 43 \mathrm{H} / 63(177) & 0.77 & 0.41\end{array}$

Distribution. Upper Miocene (FC zone) and Lower Pliocene (FB zone), Oosterhout Formation, the Netherlands. Pliocene, Kattendijk and Lillo formations at Antwerp (Wouters, 1979), Belgium. Pliocene, Coralline Crag Formation at Sutton Knoll and Orford, Suffolk, UK.

Description. Carapace, robust, elongate/subrectangular. Dorsal and ventral margins sinuous. Anterior broadly rounded; posterior somewhat truncated. In dorsal view the outline is inflated with the maximum width behind mid-length. Moderately well developed eye tubercle present just below the anterior cardinal angle. Ornament coarsely pitted/reticulate, fossae inside marginal rim rectangular. Rounded/subovate fossae surround the subcentral tubercle while a discrete cluster occur anterodorsally of this tubercle. Secondary, fine, puncta especially visible in juveniles. Weak, longitudinal, plicate muri, arising from the subcentral tubercle terminating posterodorsally. Very narrow anterior vestibulum, posterior avestibulate, ventral frontal muscle scar bilobate, inner lamella moderately broad. Marginal pore canals simple, straight/sinuous, 27 anteriorly, 14 posteriorly and at least four orally.

Remarks. Muellerina orygyma sp. nov. occurs most commonly in association with $M$. lacunosa (Jones) in the early Pliocene successions of the Netherlands. Muellerina orygyma sp. nov can be distinguished from the latter species by both its swollen mediodorsal region and reduced posterior tubercles, however, it is apparent that intermediate forms also exist between the two end member species; this being especially prevalent within ecozone B, mid Pliocene (Wood et al., 1994).

\section{Muellerina pliocenica sp. nov.}

(P1. 2, figs $2 \& 4$ )

1980 Murrayina lacunosa (Jones); Wilkinson: pl. 2, fig. 13 (non Jones, 1857).

1989 Muellerina lacunosa (Jones); Horne \& Kerr: pl. 2, fig. d (non Jones, 1857).

1989 Muellerina sp. cf. M. lacunosa (Jones); Fourniguet et al.: pl. 1, fig. 19.

Derivation of name. Named for the epoch in which it is most commonly found.

Diagnosis. Carapace elongate, subovate. Heavily denticulated, lipped, extension of the anterior margin. Fossae, cellate, irregularly disposed. Posterior dominated by three tubercles situated in the posterodorsal, posteroventral (this swelling continues anteriorly as a strong plicate ridge) and posteromedian fields, interconnected with expanded, undulose, sinuous muri.

Type locality and horizon. Klundert $43 \mathrm{H} / 63$ borehole, 219-221.5, FB zone, Oosterhout Formation, Pliocene, the Netherlands.

Material. East Anglia, 5CP, $11 \mathrm{~V}$; the Netherlands, 3CP, $24 \mathrm{~V}$. Dimensions of types.

$\begin{array}{llllc} & \text { Cat. No. } & \text { Site } & \text { Length } & \text { Height } \\ \text { Holotype ARV-M } & \text { OS14189 } & 43 \mathrm{H} / 63(163) & 0.76 & 0.32 \\ \text { Paratype ALV-F } & \text { OS14190 } & 43 \mathrm{H} / 63(163) & 0.70 & 0.34 \\ \text { Paratype ALV-M } & \text { OS14191 } & 43 \mathrm{H} / 63(163) & 0.76 & 0.33 \\ \text { Paratype ARV-F } & \text { OS14192 } & 43 \mathrm{H} / 63(170) & 0.73 & 0.32\end{array}$

Distribution. Pliocene; FB and FA2 zones, Oosterhout Formation, the Netherlands. Coralline Crag Formation at Orford and Sutton Knoll, East Anglia. Redonian (Upper Pliocene) of the St Erth Beds, Cornwall and northwest France. ?Pliocene/Pleistocene; Knocknasillage Member, Co. Wexford, Ireland.

Description. Carapace elongate/subovate, dorsal and ventral margins sinuous. Anterior margin compressed. In dorsal view,

\section{Explanation of Plate 1}

Figs 1a-c. Muellerina latimarginata (Speyer, 1863): fig. 1a, AMW/PL/016 LV-F, ext. lat. (875); fig. 1b, AMW/PL/016, int. lat. ( $\times 69$ ); fig. 1c, AMW/ PL/019, detail of central muscle scars (×292). Figs 2-3. Muellerina abyssicola (Sars, 1866): fig. 2, AMW/RNA/018 LV-F, ext. lat. ( $\times 64$ ); fig. 3, AMW/ RNA/019 R.V-M, ext. lat. (×65). Figs 4-6. Muellerina lacunosa (Jones, 1857): fig. 4, AMW/PL/023 RV-F, ext. lat. ( $\times 61$ ); fig. 5, AMW/PL/022 LV-M, ext. lat. (×57); fig. 6, AMW/PL/020 LV-F, int. lat. (×66). Figs 7-9. Muellerina dolabrata sp. nov.: fig. 7, Holotype MPK9768 RV-F, ext. lat. ( $\times 77$ ); fig. 8, Paratype MPK9770 LV-M, ext. lat. ( $\times 83)$; fig. 9a, Paratype MPK9769 LV-F, ext. lat. $(\times 80)$; fig. 9b, Paratype MPK9769, detail of central muscle scars $(\times 384)$. Figs 10-11. Muellèrina metabyssicola sp. nov.: fig. 10, Paratype MPK9773 LVA-1, ext. lat. $(\times 71)$; fig. 11a, Holotype MPK9772 RV-F, ext. lat. ( $\times 63)$; fig. 11b, Holotype MPK9772, int. lat. ( $\times 65)$. Figs 12-13. Muellerina orygyma sp. nov.: fig. 12, Holotype OS14185 LV-F, ext. lat. ( $\times 62)$; fig. 13, Paratype OS14186 RV-F, ext. lat. $(\times 64)$. 


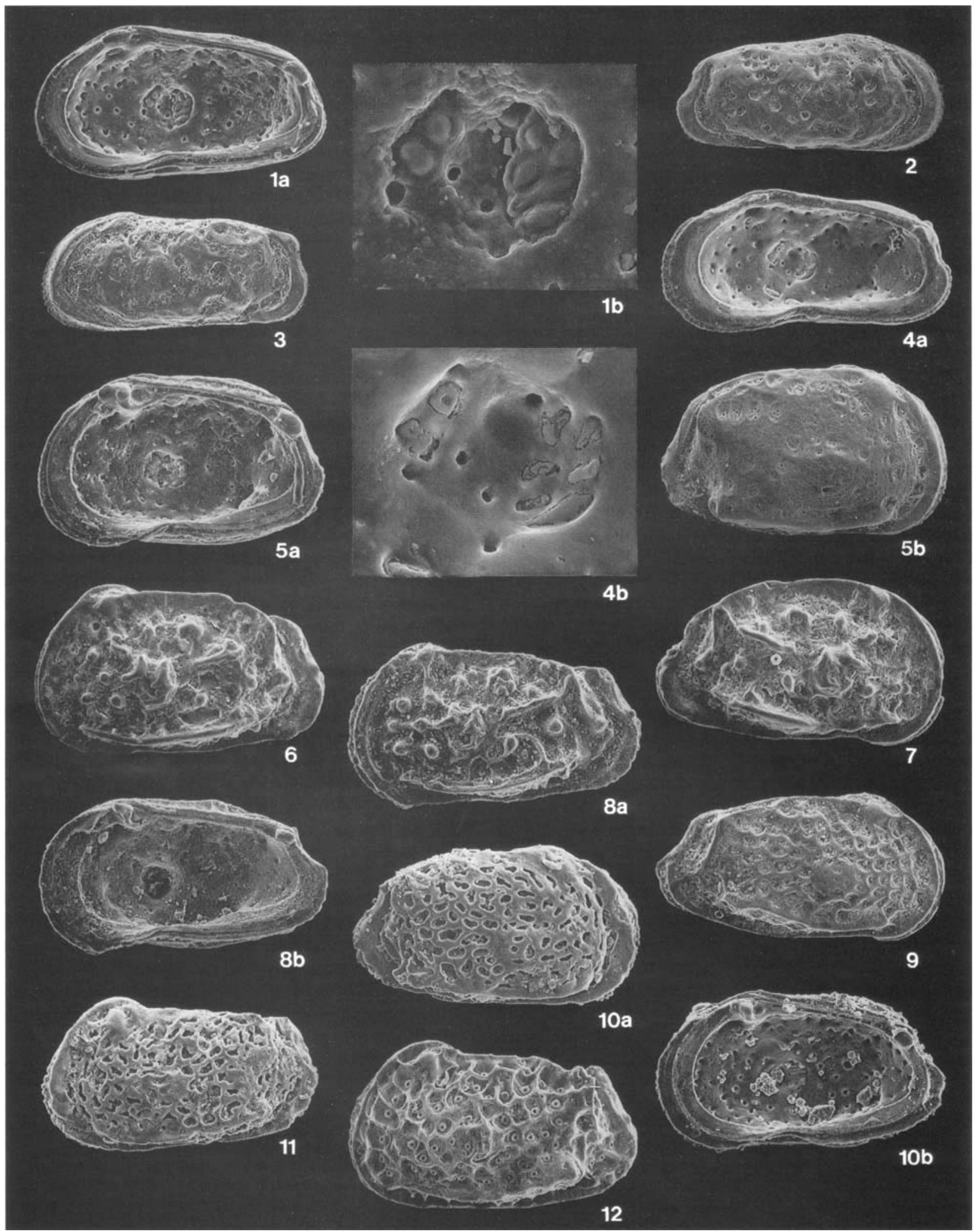

Plate 2 
listric truncated in front of posterior margin. Maximum height at or just in front of anterior cardinal angle. Triangular eye tubercle situated in front of the anterior cardinal angle. Anterior margin consists of an outer denticulated lip, broad marginal rim with elongate pits, parallel with margin, occasionally connected to form a sinuous depression. This area is separated from a single concentric row of amorphous fossae by a delicate excavate rib. Posterior margin broad, with five subcircular depressions, lipped, denticulated posteroventrally. Ornament, tuberculate, prominent dorsomedian, posterodorsal and posteroventral swellings. The latter structure tapers anteriorly to form a plicate ridge terminating in the ventromedian field. Dorsal tubercles inter-connected via an excavated rib. Scattered, subcircular, cellate fossae clustered posterodorsally. Sensillum pores common, intramural and simple. Avestibulate, inner lamella moderately broad, marginal pore canals simple, straight; 24 anteriorly, 20 orally and 13 posteriorly.

Remarks. As with species of the 'abyssicola' lineage, $M$. pliocenica sp. nov. possesses a listric truncation of the posterior margin in dorsal view, dorsomedian ridge/bar and posterior tubercles. Aside from $M$. latimarginata (Speyer), which has a range from the Oligocene to mid-Pliocene, this species has the longest recorded range; uppermost Miocene, Holland to Upper Pliocene, St. Erth Beds, Cornwall (c. 2.1-1.8 Ma, Jenkins and Houghton, 1987). It has also been recorded from younger, Pleistocene age, deposits of Co. Wexford although there are indications of reworking (Horne \& Kerr, 1989, p. 74).

Family Thaerocytheridae Hazel, 1967

Subfamily Thaerocytherinae Hazel, 1967

Genus Thaerocythere Hazel, 1967

Type species: Cythereis crenulata Sars, 1866.

Emend. Diagnosis. Carapace elongate subovate/quadrate to trapezilorm, thick shelled. Dimorphic, males proportionally more elongate, generally depressed. Ornament coarse to delicate reticulate, usually with prominent sub-central, posteroventral and posterodorsal tubercles, latter extends backwards as a generally robust, submarginal rib approximately two-thirds length of carapace. Moderately wide posterior and anterior marginal rims. Single, reticulate, concentric submarginal furrow commonly developed.

Four adductor muscle scars, middle two somewhat elongate, two frontal scars in oblique row. Hinge strong holamphidont. Avestibulate, marginal pore canals numerous and straight, 2545 anteriorly, 12-21 posteriorly. Moderately strong anterior selvage.

Remarks. Two subgenera Thaerocythere (Thaerocythere), $T$.
(Notopleura) and a questioned third have been erected by Liebau (1991) using sculpture mapping of the mesh (or cell) patterns, pore cones and muscle scars. It is clear from Liebau's work that a number of the Tertiary thaerocytherid species, especially those outside of the European realm, have no or only questionable affiliations with these new subgenera; most notably are $T$. sagittata Liebau, 1991; T. mayburyae Cronin, 1991; T. woutersi sp. nov.; $T$. ruespelensis (Uffenorde, 1981); $T$. schmidtae (Malkin, 1953) and T. carolinensis Hazel, 1977. Without creating a number of new monospecific subgenera, which the present authors feel would only cause additional complications, difficulties in assigning species to the subgenera level cannot be overcome. We have, therefore, refrained from using the new subgenera with respect to this genus.

\section{Thaerocythere crenulata (Sars, 1866)}

(P1. 2, fig. 5)

1866 Cythereis crenulata Sars: 39.

1889 ?Cythere crenulata (Sars); Brady \& Norman: 158, pl. 15, figs $5 \& 6$.

1941 Cythereis (Eucythereis) crenulata Sars; Elofson: 60.

1967 Thaerocythere crenulata (Sars); Hazel: 25, pl. 4, figs 2-5, 8; pl. 9 , fig. 4 .

1991 Thaerocythere (Thaerocythere) crenulata (Sars); Liebau: 149.

Diagnosis. Carapace subquadrate in lateral view. Anterior denticulated, broad to obliquely rounded, posterior somewhat truncated. Subdued reticulation, fossae minutely pappilate. Short submarginal dorsal rib, both ends terminate in knobs. In dorsal view posterior compressed. Inner margin moderately wide, radial pore canals simple, straight; selvage moderately developed.

Material. In excess of 2000 specimens.

Dimensions.

$\begin{array}{lllll} & \text { Cat. No. } & \text { Site } & \text { Length } & \text { Heigh } \\ \text { ALV-M } & \text { AMW/PL/001 } & 1962 / 160(8) & 0.74 & 0.44 \\ \text { ARV-F } & \text { AMW/PL/002 } & 1962 / 160(8) & 0.75 & 0.47\end{array}$

Distribution. Recent; Pan Arctic and amphiatlantic species. Commonly encountered on the shelf of the northeast Atlantic between the Bay of Biscay and Greenland (Cronin et al., 1992). Hazel (1968) indicated the presence of late glacial specimens, at depth, between Capes Hatteras and Cod. Holocene; Bay of Biscay (Peypouquet, 1971, 1973).

Remarks. Only this cryophilic, amphiatlantic type species and Thaerocythere hoptonensis (Brady et al., 1874) have been recorded from the Recent. Also see Thaerocythere praecrenulata sp. nov for remarks.

\section{Explanation of Plate 2}

Fig. 1. Muellerina orygyma sp. nov.: fig. 1a, Paratype OS14186 RV-F, int. lat. $(\times 65)$; fig. 1b, Paratype OS14186, detail of central muscle cars $(\times 260)$. Figs 2-4. Muellerina pliocenica sp. nov.: fig. 2, Holotype OS14189 RV-M, ext. lat. (×61); fig. 3, Paratype OS14191 LV-M, ext. lat. ( $\times 61)$; fig. 4a, Paratype OS14192 RV-F, int. lat. (×69); fig. 4b, Paratype OS14192, detail of central muscle scar ( $\times 336)$. Fig. 5a-b. Thaerocythere crenulata (Sars, 1866): fig. 5a, AMW/RNA/002 RV-F, int. lat. $(\times 66)$; fig 5b, AMW/RNA/002, ext. lat. ( $\times 66)$. Figs 6-8. Thaerocythere hoptonensis $($ Brady et al., 1874): fig. 6; Holotype 2.04.21 CpLV-F, ext. lat. ( $\times 57)$; fig. 7, Holotype 2.04.21 CpRV-F, ext. lat. ( $\times 57)$; fig. 8a, AMW/PL/026 LV-M, ext. lat. ( $\times 70)$; fig 8b, AMW/PL/026, int. lat. ( $\times 70)$. Fig. 9. Thaerocythere mayburyae Cronin, 1991, AMW/PL/004 RV-M, ext. lat. $(\times 66)$. Figs 10-11. Thaerocythere oedichilus (Brady, 1878): fig. 10a, AMW/PL/007 RV-F, ext. lat. ( $\times 70)$; fig. 10b, AMW/PL/007, int. lat. ( $\times 70)$; fig. 11, AMW/PL/008 LV-M, ext. lat. (×67). Fig. 12. Thaerocythere trapezia (Brady, 1878), AMW/PL/011 LV-M, ext. lat. (×63). 
Thaerocythere hoptonensis (Brady, Crosskey \& Robertson, 1874) (Pl. 2, figs 6-8)

1874 Cythere hoptonensis nov. sp. Brady, Crosskey and Robertson: 168, pl. 14, figs 4-6.

1982 Quadracythere hoptonensis (Brady et al.); Liebau: 233.

1991 Thaerocythere (Notopleura) hoptonensis (Brady et al.); Liebau: 153.

1991 Thaerocythere (Notopleura) lusitanica n. sp. Liebau; 152153 , pls $80-82$; pl. 92 , fig. 5 .

Diagnosis. Elongate, subovate in lateral view; dorsal margin obliquely convex, ventral sinuous. Ornament consists of subovate fossae, marginally subquadrate; radial muri raised with respect to concentric component; pore-conuli common, situated on micropappilate solum where they are proximal to the muri, also present in subconcentric row mid-way between centre and margin (most common above mid-height) were they may be depressed. Well developed anterodorsal and short posterodorsal ridges, latter angled between posterior cardinal angle and subcentral tubercle.

Dimensions of types.

$\begin{array}{lllll} & \text { Cat. No } & \text { Site } & \text { Length } & \text { Height } \\ \text { Holotype CpALV-F } & 2.04 .21 & \text { Hopton Cliff } & 0.87 & 0.48 \\ \text { Holotype CpARV-F } & 0.89 & 0.48 & & \\ \text { ALV-M } & \text { AMW/PL/026 } & \text { Neutral Farm } & 0.72 & 0.40 \\ \text { ARV-M } & \text { AMW/PL/027 } & \text { Neutral Farm } & 0.72 & 0.40\end{array}$

Distribution. Pliocene; Butleyan stage of the Red Crag Formation, Neutral Farm, Butley (TM 372811) (Lord et al., 1988); Upper Pliocene (Redonian); Pallau II borehole, northwest France (C. A. Maybury, pers. comm.). ?Pleistocene; Hopton Cliff, Norfolk, UK. Recent; Sao Martinho do Porto, Portugal (Liebau, 1991), dredged off Muros, Spain $\left(42.78^{\circ} \mathrm{N}, 9.08^{\circ} \mathrm{W}\right)$ (Brady \& Norman, 1889) and a single specimen from a depth of $235 \mathrm{~m}$ on the northern Moroccan shelf $\left(35.58^{\circ} \mathrm{N}, 6.63^{\circ} \mathrm{W}\right)$.

Remark. Re-examination of the types revealed that $T$. (Notopleura) lusitanica Liebau, 1991 is in fact a junior synonym of T. hoptonensis. Other species considered, by Liebau, 1991 (p. 150 ), to be members of the subgenus Thaerocythere (Notopleura) included $T$. transiens (Moos, 1963) and $T$. nodoreticulata (Bassiuoni, 1962).

Thaerocythere mayburyae Cronin, 1991

(P1. 2, fig. 9)

1889 Cythere trachypora Jones: 24, pl. 3, figs 9a \& $9 b$ (non Jones, 1857).

1989 Thaerocythere sp. Horne \& Kerr: pl. 2, fig. c.

1991 Thaerocythere mayburyae n. sp. Cronin: 777, pl. 10, figs $1-7$.

Diagnosis. (after Cronin, 1991, p. 777). Carapace thick, subquadrate; surface characterized by well developed anterior marginal ridge, ventral and marginal ridges connected by a short oblique posterodorsal ridge; dorsomedian ridge variably developed. Subcentral tubercle very large, smooth to weakly pitted. Material. East Anglia, 2CP, 9V.

Dimensions.

$\begin{array}{lllll} & \text { Cat. No. } & \text { Site } & \text { Length } & \text { Height } \\ \text { LV/A-1 } & \text { AMW/PL/003 } & \text { Chillesford } & 0.70 & 0.39 \\ \text { ARV-M } & \text { AMW/PL/004 } & \text { Chillesford } & 0.76 & 0.40 \\ \text { ALV-F } & \text { AMW/PL/005 } & \text { Chillesford } & 0.74 & 0.43\end{array}$

Distribution. Pliocene; Chillesford Sand Member, Norwich Crag Formation at Chillesford Church Pit, East Anglia, UK; Tapes, Mactra and Serripes zones, Tjörnes, Iceland. Upper Pliocene (Redonian); St Erth Beds, Cornwall, UK. ?Pliocene/Pleistocene; Knocknasilloge Member, County Wexford, Ireland.

Remarks. This species has been identified in the Hopton Cliff faunal slide of Brady et al. (1874), where it is described as Cythere macropora Bosquet (non Bosquet, 1852). A cryophilic species which first appeared in the Tapes Zone of Tjörnes ( $c$. 3.40-3.15 Ma, Cronin, 1991). Clearly allied with Thaerocythere sp. A from the Coralline Crag Formation of East Anglia (see remarks).

Thaerocythere oedichilus (Brady, 1878)

(P1. 2, figs 10 \& 11)

1878 Cythere oedichilus nov. sp. Brady: 388 , pl. 64, figs 1a-1d.

1967 Thaerocythere? oedichilus (Brady); Hazel: 25 and 26.

1991 Thaerocythere (Thaerocythere) oedichilus (Brady, 1879 [sic]); Liebau: 158, pl. 90, figs 1-4.

Diagnosis. Carapace, robust, subquadrate. Anterior obliquely rounded with broad denticulated marginal rim; posterior, angular, subtruncate. Dorsal margin weakly convex, ventral sinuous, converging posteriorly. Reticulation intricate, labyinthine network of elongate/ovate cellate fossae. Muri inflated and raised either side of overgrown subcentral tubercle. Subventral ridge with alate posteroventral termination. Simple intermural and conjunctive pores common.

Material. East Anglia, 39V; the Netherlands, 22CP, $50 \mathrm{~V}$.

Dimensions.

$\begin{array}{lllll} & \text { Cat. No. } & \text { Site } & \text { Length } & \text { Height } \\ \text { ALV-F } & \text { AMW/PL/006 } & 43 \mathrm{H} / 63(173) & 0.68 & 0.41 \\ \text { ARV-F } & \text { AMW/PL/007 } & 43 \mathrm{H} / 63(173) & 0.71 & 0.41 \\ \text { ALV-M } & \text { AMW/PL/008 } & 43 \mathrm{H} / 63(170) & 0.71 & 0.39\end{array}$

Distribution. ?Miocene; ?Antwerp and Edgam sands, Belgium; FCl zone, Oosterhout Formation, the Netherlands. Pliocene; Duerne and Lillo formations of Belgium; FB and FA2 zones, Oosterhout Formation; Coralline Crag Formation at Orford and Sutton Knoll, UK; Waltonian stage Red Crag Formation, Walton-on-the-Naze, UK and Butleyan stage Red Crag Formation, Crag Farm, Suffolk, UK.

Remarks. On the basis of macroreticulation Liebau (1991) placed this species and both $T$. crenulata and $T$. sagittata Liebau, 1991 within Thaerocythere (Thaerocythere) Liebau, 1991. The outline of this species resembles $T$. crenulata in many respects although its ornament is markedly different.

\section{Thaerocythere trachypora (Jones, 1857)}

$$
\text { (Pl. 3, fig. 1) }
$$

1857 Cythere trachypora Jones; 36, pl. 3, figs 9f-i.

non 1889 Cythere trachypora Jones; Jones \& Sherborn: 24, pl. 3, figs 9a \& 9b (=T. mayburyae Cronin, 1991).

1980 Quadracythere macropora (Bosquet); Wilkinson: pl. 2, figs $16 \& 17$ (non Bosquet, 1852).

?1981 'Quadracythere' ruspelensis n. sp. Uffenorde, pl. 7, fig. 21. 1988 Thaerocythere sp. Lord, Horne \& Robinson; 4.

?1991 Thaerocythere whatleyi $\mathrm{n}$. sp. Cronin; 780, pl. 10, figs 11, $12 \& 14$.

Diagnosis. Robust, quadrate, species of Thaerocythere with raised anterior cardinal angle in LV, dorsal margin sinuous with 
concavity at mid length. Ornament composed of equally well developed radial and concentric arranged muri about solid subcentral tubercle. Muri angled, above mid-height, from posterior cardinal angle to mid height at the anterior margin. Fossae subquadrate, pore-conuli common and central on solum, intermural and conjunctive pores rare.

Material. East Anglia, $77 \mathrm{CP}, 160 \mathrm{~V}$; the Netherlands, 3CP, $16 \mathrm{~V}$. Dimensions.

$\begin{array}{lllll} & \text { Cat. No. } & \text { Site } & \text { Length } & \text { Height } \\ \text { ACp-F } & \text { AMW/PL/009 } & \text { OSC1/OR12 } & 0.75 & 0.47 \\ \text { ARV-M } & \text { AMW/PL/010 } & \text { OSC1/OR15 } & 0.75 & 0.47\end{array}$

Distribution. Pliocene; Coralline Crag Formation; Waltonian, Butleyan and Newbournian stages of the Red Crag Formation. FB, FA2 and FA1 (Pleistocene) of the Oosterhout and Maasslius formations, Holland. Oorderen Sands, Belgium (K. Wouters, pers. comm.).

Remarks. It appears likely that the rather worn specimens of $T$. whatleyi Cronin, 1991 from the Pliocene of Iceland are synonymous with this species. $T$. trachypora has retained a number of traits common to $T$. vermiculata sp. nov., notably two equally robust, anteromedian, longitudinal ridges and the general structure of both raised and depressed muri in the posterodorsal region.

\section{Thaerocythere trapezia (Brady, 1878)}

(P1. 2, fig. 12)

1878 Cythere trapezia nov. sp. Brady: 391-392, pl. 66, figs 4a-d. Diagnosis. Carapace sub-trapezoidal in lateral view, anterior obliquely rounded, margin reduced to a fine ridge. Dorsomarginal ridge moderately well developed. Reticulation composed of polygonal/quadrate, elongate quadrate at margins, fossae concentric and radial mural component equally developed. Large pore-conuli, peripheral on caperate solum. Subvertical truncation of reticulation belong posterior cardinal angle. Eye tubercle, conical and mounted on murus below anterior cardinal angle.

Material. The Netherlands, $1 \mathrm{CP}, 5 \mathrm{~V}$.

Dimensions.

$\begin{array}{lllll} & \text { Cat. No. } & \text { Site } & \text { Length } & \text { Height } \\ \text { ALV-M } & \text { AMW/PL/011 } & 43 \text { H63(153) } & 0.79 & 0.47 \\ \text { ARV-M } & \text { AMW/PL/012 } & 43 \text { H63(153) } & 0.79 & 0.43\end{array}$

Distribution. Pliocene; FB zone, Oosterhout Formation, the Netherlands; Luchtbal (K. Wouters, pers. comm.) and Oorderen Sands, Lillo Formation, Belgium and Coralline Crag Formation at Orford, Sutton Knoll and Gedgrave (K. Wouters, pers. comm.).

Remarks. This species is a close relative of $T$. vermiculata sp. nov., a species restricted to the Miocene of the Netherlands and Belgium. Comparison of the macrorecticulation reveals a number of morphological analogues, notably the trapezoidal outline and overall carapace dimensions. $T$. vermiculata sp. nov. is easily distinguish from $T$. trapezia by the presence of two, longitudinal and inflated anteromedian ridges, similar to those developed in $T$. trachypora.

Thaerocythere biformis sp. nov.

$$
\text { (P1. 3, figs. 2-5) }
$$

Derivation of name. Latin; biformis $=$ having two forms. Pertaining to the existence of two ecophenotypic variants of this species.
Diagnosis. Trapezoidal in lateral view, fossae subovate. Poreconuli commonly developed with apophysis, peripherally situated on micropapillate solum. Strongly developed submarginal, anteroventral and dorsal ridges, latter reclined ' $J$ '-shaped. Intricate, pinched, mediodorsal nodes present.

Type locality and horizon. Klundert $43 \mathrm{H} 63$ borehole, $256.50-$ $259 \mathrm{~m}$, Upper Miocene, Oosterhout Formation, the Netherlands.

Material. The Netherlands, 5CP, 95V.

Dimensions of types.

\begin{tabular}{|c|c|c|c|c|}
\hline & Cat. No. & Site & Length & Heigh \\
\hline \multicolumn{5}{|c|}{ Thermophilic forms } \\
\hline Holotype ARV-F & OS14193 & $43 \mathrm{H} / 63(178)$ & 0.80 & 0.47 \\
\hline Paratype ALV-F & OS14194 & $43 \mathrm{H} / 63(179)$ & 0.81 & 0.51 \\
\hline Paratype ALV-M & OS14195 & $43 \mathrm{H} / 63(179)$ & 0.75 & 0.43 \\
\hline Paratype ARV-M & OS14196 & $43 \mathrm{H} / 63(178)$ & 0.77 & 0.43 \\
\hline \multicolumn{5}{|l|}{ Cryophilic forms } \\
\hline Paratype ALV-F & OS14197 & $43 \mathrm{H} / 63(174)$ & 0.81 & 0.48 \\
\hline Paratype ARV-F & OS14198 & $43 H / 63(174)$ & 0.83 & 0.47 \\
\hline Paratype ALV-M & OS14199 & $43 \mathrm{H} / 63(174)$ & 0.82 & 0.50 \\
\hline Paratype ARV-M & OS 14200 & $43 \mathrm{H} / 63(174)$ & 0.78 & 0.43 \\
\hline
\end{tabular}

Distribution. Upper Miocene (FCl zone) and Lower Pliocene (FB zone); Oosterhout Formation, the Netherlands. Upper Miocene; Dessel and Duerne sands, Diest Formation, Belgium (K. Wouters, pers. comm.).

Description. Heavily calcified, sub-trapezoidal in lateral view. Dorsal margin of RV straight with posterior irregularities, LV arched, ventral margin convex with convexity behind anterior margin. Anterior margin finely denticulated, obliquely rounded with broad angular margin. Posterior denticulated, subtruncated, dorsal region straight or concave, extremity below mid height. Eye tubercle heavily swollen, broadly conical and mounted on submarginal murus. Ornament composed large, irregular, subtriangular/subovate. Radial and concentric murus equally well developed.

Pore-conuli commonly developed, with apophysis, peripheral on micropapillate solum. Robust, submarginal, ridge connecting anterior cardinal angle with posteroventral region, posterior termination inflated, angular and bifurcate. Dorsal margin reinforced with irregular, lateral, ridge forming an inclined ' $U$ ' at the posterior cardinal angle. Two 'pinched' nodes developed below dorsal margin in the dorsomedian field.

Inner lamella broad, radial pore canals numerous and straight; 45 anteriorly, 6 orally, 17 posteriorly; selvage broad, well developed.

Remarks. Two ecophenotypes of $T$. biformis sp. nov. occur, both forms exhibit an exceptionally high level of reciprocity in the disposition of macroreticulation. The first, and oldest form, is predominantly found in sediments of upper Miocene age (Diest Formation, Belgium, K. Wouters pers comm., and the FCl Zone, Oosterhout Formation) and is considered by Wood et al. (1994) to have existed in a subtropical environment. This thermophilic form is characterized by finely chiselled muri. The second, cryophilic, form is restricted to ecozone A (first phase Lower Pliocene cooling) of the Netherlands and is characterized by a plicate swelling of muri and ridges. The earlier, thermophilic, form of $T$. biformis sp. nov, is similar, in many respects, to $T$. gramanni Liebau, 1991 from the Reinbekium (Middle Miocene) of northern Germany. Both species possess similarities 

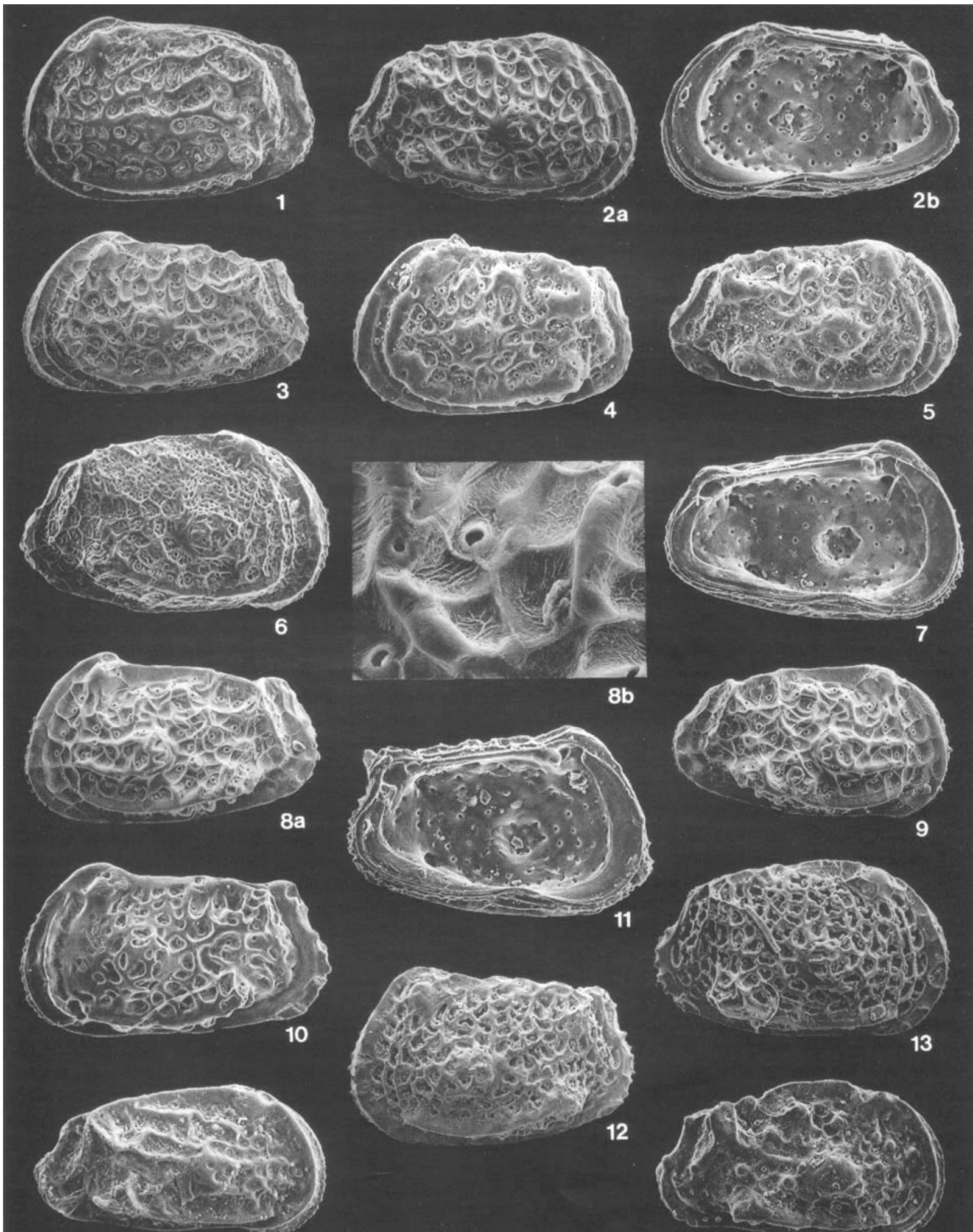

Plate 3 
in form of posterior and dorsomedian swellings as well as in the disposition of muri and fossae, however, $T$. gramanni is considerable smaller though proportionally more elongate and lacks the submarginal anterior ridge.

\section{Thaerocythere praecrenulata sp. nov.}

(Pl. 3, figs 6 \& 7)

Derivation of name. Latin; prae = before. Pertaining to its possible ancestral links with $T$. crenulata (Sars, 1865).

Diagnosis. Carapace subquadrate in lateral view; anterior obliquely rounded, finely denticulated. Ornament composed of a first order polygonal, sub-radial, reticulation with low muri; more elongate parallel to anterior margin. Second order fabric of small sub-triangular/polygonal muri, surrounding commonly marginal pore-conuli.

Type locality and horizon. Klundert $43 \mathrm{H} / 63$ borehole, 239-241; FB zone. Oosterhout Formation, Upper Miocene, the Netherlands.

Material. The Netherlands, 1CP, 3V.

Dimensions of types.

$\begin{array}{lllll} & \text { Cat. No. } & \text { Site } & \text { Length } & \text { Height } \\ \text { Holotype ALV-?F } & \text { OS14201 } & 43 \mathrm{H} / 63(171) & 0.79 & 0.50 \\ \text { Paratype ARV-?F } & \text { OS14202 } & 43 \mathrm{H} / 63(171) & 0.84 & 0.51 \\ \text { Paratype RVA-1 } & \text { OS14203 } & 43 \mathrm{H} / 63(171) & 0.74 & 0.42\end{array}$

Distribution. Lower Pliocene, FB zone, Oosterhout Formation, the Netherlands.

Description. Carapace quadrate; dorsal margin straight to slightly convex, ventral concave with convexity behind anterior margin. Anterior finely denticulated, obliquely rounded with raised cardinal angle in LV; posterior subtruncate with concavity above mid height. Maximum width submarginal to posterior. Small, well defined eye tubercle.

First and second order reticulation, sub-radial disposed, about finely punctate subcentral tubercle. Polygonal, first order fossae with low relief muri, more elongate parallelled to anterior margin. Second order composed of a fine tesselation of subtriangular/polygonal micro-muri surrounding, commonly peripherally sited, pore-conuli. Muri suppressed or absent at dorsal margin.

Inner lamella moderately wide, avestibulate, marginal radial pore canais, numerous; 12 posteriorly, nine orally and 27 anteriorly, selvage moderately developed.

Remarks. Proposed ancestor of $T$. crenulata (Sars, 1866). Size and distribution of primary macrorecticulation in both species is clearly analogous, however, the secondary tessellation of the solum in the Pleistocene/Recent species is much simplified, being finely punctate or papillate. Both species are cryophilic, $T$. crenulata is restricted, on the northeast Atlantic shelf, to the European Realm where it attains its acme within the Norwegian Province (sensu Wood and Whatley, 1994). T. praecrenulata sp. nov. has, as yet, only been found in ecozone A, early Pliocene, of the Netherlands (first phase Pliocene cooling; Wood et al., in 1994), where it occurs in association with other cryophilic species; Acanthocythereis tuberculatus (Norman, 1865), Palmenella limicola (Norman, 1865), Elofsonella concinna (Jones, 1857) and Neomonoceratina tsurugaskensis (Tabuki, 1986).

\section{Thaerocythere vermiculata sp. nov.}

(Pl. 3, figs 8 \& 9)

1878 Cythere macropora Bosquet; Brady: 392-392, pl. 66, figs $6 \mathrm{a}-\mathrm{d}$ (non pl. 67, fig. 1a-d=Thaerocythere woutersi sp. nov.) (non Bosquet, 1852).

Derivation of name. Latin; vermiculat $a=$ worm like. Pertaining to the fine anastomosing secondary microreticulation present on the solum.

Diagnosis. Elongate-ovate/subquadrate species of Thaerocythere characterized by a well developed dorsal lateral ridge extending from the eye backwards towards termination in front of the posterior margin at its mid-height. Reticulation consists of a network of plicate muri, in which the concentric component may be subdued. Fossae, irregular, polygonal with common poreconuli; fine secondary reticulation of anastomosing micromuri on caperate sola. Two sub-parallel, longitudinal, swollen muri developed in the anteromedian region, projecting from the subcentral tubercle to the anterior margin.

Type locality. Klundert $43 \mathrm{H} 63$ borehole, $254-256.50 \mathrm{~m}$, FC1 zone, Upper Miocene, the Netherlands.

Material. The Netherlands, 33V.

Dimensions of types.

$\begin{array}{llllc} & \text { Cat. No. } & \text { Site } & \text { Length } & \text { Height } \\ \text { Holotype ALV-M } & \text { OS14204 } & 43 \mathrm{H} / 63(177) & 0.79 & 0.46 \\ \text { Paratype ARV-M } & \text { OS14205 } & 43 \mathrm{H} / 63(177) & 0.79 & 0.43 \\ \text { Paratype ALV-F } & \text { OS14206 } & 43 \mathrm{H} / 63(177) & 0.80 & 0.49 \\ \text { Paratype ARV-F } & \text { OS14207 } & 43 \mathrm{H} / 63(177) & 0.80 & 0.52\end{array}$

Distribution. Restricted to the FCl zone (Upper Miocene) and FB, lowest Pliocene (ecozone A) of the Netherlands. Duerne Sand, Upper Miocene, Belgium (K. Wouters, pers. comm.).

Description. Carapace subquadrate/elongate subovate, dorsal margin straight to weakly convex, cardinal angle in LV raised. Anterior denticulated, obliquely rounded; posterior subtruncate to ovate in LV, RV subtruncate. Surface strongly reticulate, irregular polygonal fossae with carinate and plicate muri, concentric component subdued. Secondary reticulation present on sola of the fossae in the form of anastomosing micropapillae.

Explanation of Plate 3.

Fig. 1. Thaer acythere trachypora (Jones, 1857): fig. 1, AMW/PL/009 CpLV-F, ext. lat. ( $\times 65$ ). Figs 2-5. Thaerocythere biformis sp. nov. (figs 2-3 thermophilic form): fig. 2a, Holotype OS14193 RV-F, ext. lat. ( $\times 61)$; fig. 2b, Holotype OS14193, int. lat. ( $\times 63)$; fig. 3, Paratype OS14195 LV-M, ext. lat. ( $\times 64)$; (figs 4-5 cryophilic form): fig. 4, Paratype OS14197 LV-F, ext. lat. ( $\times 57)$; fig. 5, Paratype OS14200 RV-M, ext. lat. ( $\times 63$ ). Figs 6-7. Thaerocythere praecrenulata sp. nov.: fig. 6, Paratype OS14202 RV-?F, ext. lat. $(\times 61)$; fig. 7, Holotype OS14201 LV-?F, int. lat. $(\times 64)$. Figs 8-9. Thaerocythere vermiculata sp. nov.: fig. 8a, Holotype OS14204 LV-M, ext. lat. ( $\times 63)$; fig. 8b, Holotype OSI4204, detail of microrecticulation ( $\times 323$; fig. 9, Paratype OS14205 RV-M, ext. lat. $(\times 60)$. Figs 10-11. Thaerocythere wittei sp. nov.: fig. 10, Paratype OS14209 LV-M, ext. lat. $(\times 60)$; fig. 11, Holotype OS 14208 LV-F, int. lat. (×63). Figs 12-13. Thaerocythere woutersi sp. nov.: fig. 12, Holotype OS14212 LV-F, ext. lat. $(\times 61)$, fig. 13, Paratype OS14215 RV-M, ext. lat. (×64). Fig. 14. Thaerocythere sp. A, AMW/PL/013 RV-M, ext. lat. (×63). Fig. 15. Thaerocythere sp. B, AMW/PL/ 024 RV-F, ext.. lat. $(\times 65)$. AMW/PL/024 RV-F, ext. lat. $(\times 65)$. 
Pore-conuli peripheral on solum, with apophysis; rare, simple disconjunctive pores. Eye tubercle mounted on, carinate, murus which projects backwards in an arcuate curve towards termination at mid height of posterior margin. Subventral ridge terminates posteriorly in swollen bifurcation. Two sub-parallel, plicate, muri extend from a masked subcentral tubercle, forward towards the anterior margin.

Inner lamella moderately wide, marginal radial pore canals straight/sinuous; 35 anteriorly, $6+$ orally and 18 posterioriy. Anterior selvage.

Remarks. This species was original described by $\mathbf{K}$. Wouters (pers. comm.) from the Duerne Sands Member of Belgium. Its morphological affinities with the younger mid-Pliocene species, $T$. trachypora are unquestionable (see remarks).

Thaerocythere wittei $\mathrm{sp}$. nov.

(Pl. 3, fig. 10)

1991 Thaerocythere (Thaerocythere) sp. LA58 Liebau: 158, pl. 90, fig. 5.

Derivation of name. In recognition of the enormous help given by Dr Leendert Witte of the Royal Dutch Geological Survey in suppling both samples and information for this study and also of his important work on West African Ostracoda.

Diagnosis. Carapace elongate rectangular with sub-parallel dorsal and ventral margins. Marked concavity of posterodorsal margin resulting in a sub-triangular posterior extremity. Surface pitted with moderately large, deep, subcircular to slit-like cellate fossae, coalescing posteriorly, radially disposed about high subcentral tubercle.

Type locality and horizon. Klundert 43H/63 borehole, 239-241.5, FB zone, Oosterhout Formation, Pliocene, the Netherlands.

Material. East Anglia, 1CP, 28V; the Netherlands, 3CP, $24 \mathrm{~V}$. Dimensions of types.

\section{Cat. No. Site Length Height}

$\begin{array}{llll}\text { Holotype ARV-F OS14208 } & 43 \mathrm{H} / 63(171) & 0.92 & 0.48\end{array}$

$\begin{array}{llll}\text { Paratype ALV-M OS14209 } & 43 \mathrm{H} / 63(171) & 0.87 & 0.48\end{array}$

$\begin{array}{lllll}\text { Paratype LV A-2 OS14210 } & 43 \mathrm{H} / 63(174) & 0.71 & 0.38\end{array}$

$\begin{array}{llll}\text { Paratype RV A-3 OS14211 } & 43 \mathrm{H} / 63(158) & 0.53 & 0.30\end{array}$

Distribution. Upper Miocene to Upper Pliocene (FC-FA2 zones); Oosterhout Formation, the Netherlands. Mid to Upper Pliocene Coralline Crag Formation, Orford, UK; Waltonian and Butleyan stages of the Red Crag Formation at Walton-onthe-Naze and Neutral Farm, UK. Upper Pliocene and ?earliest Pleistocene, Belgium (Liebau, 1991, p. 158).

Description. Carapace heavily calcified, subrectangular in lateral view. Dorsal margin concave in $\mathrm{LV}$ with moderately raised anterior cardinal angle, RV straight; ventral sinuous to slightly convex in LV, sinuous in RV. Anterior obliquely rounded with numerous, webbed, marginal denticles. Posterior angular/subtriangular. Surface pitted with moderately large, deep, slit-like to subcircular cellate fossae, coalescing posteriorly. Pore-conuli peripheral on solum, rarer disconjunctive, simple, normal pores. Posterodorsal tubercle forms a forward reclined ' $U$ '. Inner lamella moderately broad, radial pore canals numerous, straight and evenly spaced; 29 anteriorly, $4+$ orally, 18 posteriorly, selvage well developed.

Remarks. This species was placed with $T$. oedichilus (Brady, 1878) in the subgenus Thaerocythere (Thaerocythere) by Liebau (1991). Although, both species possess heavily cellated fossae, subdued reticulation on the dorsal margin and a sub-triangular posterior the overall structure of their ornament is very different.

Thaerocythere woutersi $\mathrm{sp}$. nov.

(Pl. 3, fig. 11-13)

1878 Cythere macropora Bosquet; Brady: 392-392, pl. 67, figs la-d (non pl. 66, figs $6 \mathrm{a}-\mathrm{d}=T$. vermiculata sp. nov.) (non Bosquet, 1852).

?1990 'Quadracythere' sp. Uffenorde; pl. 1, fig. 10.

Derivation of name. In honour of $\mathrm{Dr} K$. Wouters for his contribution to the study of Neogene Ostracoda from Belgium. Diagnosis. Quadrate species of Thaerocythere characterized by a serrated dorsal margin and finely sculptures reticulation comprising a basket-like ponticulate tegman bearing disconjunctive normal pores and ingrowing spines edging fossae. Poreconuli common and proximal to muri.

Type locality and horizon. Klundert $43 \mathrm{H} 63$ borehole, 239 $241.50 \mathrm{~m}$, Lower Pliocene, Oosterhout Formation, the Netherlands.

Material. The Netherlands, $8 \mathrm{CP}, 110 \mathrm{~V}$.

Dimensions of types. Cat. No.

Holotype ALV-F OS14212 43H/63(171)

Paratype ARV-F OS14213 43H/63(177)

Length Height

Paratype ALV-F OS14214 43H/63(171)

Paratype ARV-M OS14215 43H/63(171)

0.82

0.50

$0.82 \quad 0.48$

$0.79 \quad 0.50$

$0.78-0.48$
0.78

$\begin{array}{lllll}\text { Paratype Cp-F } & \text { OS14216 } & 43 \mathrm{H} / 63(171) & 0.78 & 0.51\end{array}$

Distribution. Upper Miocene and Lower Pliocene (ecozone A) of the Netherlands. Middle and Upper Miocene, ?Brecham and Diest formations, Belgium (Brady, 1878). Upper Miocene, parvipunctata superzone (Uffenorde, 1990, p.372), Wusterheide, northern Germany.

Description. Thick shelled, sub-trapezoidal in lateral view. Dorsal margin serrated, LV broadly concave, RV straight or slight convex. Ventral margin broadly convex. Anterior margin obliquely rounded with very fine radial muri, posterior truncate. Conspicuous eye tubercle mounted on reticulate tegman. Carapace intricate, reticulate with fine subquadrate/ovate 'basket-like' sculpture with both radial and concentric components comprising ponticulate tegmina bearing disconjunctive normal pores and minute, ingrowing, spines edging fossae. Poreconuli common, proximal to muri. Dorsolateral ridge terminates posteriorly in angular, wedge shaped, swelling. Weakly projecting posterodorsal structure of cellate, cross-weaved, ribs.

Inner lamella broad, radial pore canals, numerous; especially in anteroventral quadrant, anterior 28 , orally $3+$, posterior 15 . Selvage broad, well developed.

Remarks. Its outline in lateral view is similar to that of another Upper Miocene species T. nodoreticulata (Bassiouni, 1962). Both species are characterized by a serrated dorsal margin, however, $T$. woutersi $\mathrm{sp}$. nov. is both longer and possess a rather distinctive ornament, whereas in $T$. nodoreticulata the celation. of the fossae is complete.

\section{Thaerocythere sp. A}

(P1. 3, fig. 14)

Diagnosis. Elongate ovate in lateral view. Well developed anterodorsal marginal ridge terminating posteriorly at midheight on the sub-margin; this peripheral structure is connected 
to the subcentral tubercle via a ridge attached to the posterior cardinal angle. Muri within the dorsomedian field parallel this obliquely angled ridge.

Distribution. Coralline Crag Formation at Sutton Knoll and Orford, UK.

Type locality and horizon. Sutton Knoll, sample S3, Coralline Crag Formation, Pliocene, East Anglia, UK.

Material. East Anglia, 7V.

Dimensions.

$\begin{array}{lllcc} & \text { Cat. No. } & \text { Site } & \text { Length } & \text { Height } \\ \text { ARV } & \text { AMW/PL/013 } & \text { Sutton Knoll (S4) } & 0.78 & 0.38 \\ \text { RV ?A-1 AMW/PL/014 } & \text { Sutton Knoll (S3) } & 0.70 & 0.38 \\ \text { LV A-1 } & \text { AMW/P1/015 } & \text { Sutton Knoll (S3) } & 0.61 & 0.36\end{array}$

Remarks. This species has a number of morphological affinities with T. mayburyae Cronin, 1991 and may be a possible evolutionary precursor. Both species posses a marginal ridge, eyes mounted on reticulation and similar carapace proportions, however, in $T$. $s p$. A the dorsomarginal ridge is strongly developed and overhangs this periphery along most its length, muri heavily calcified.

\section{Thaerocythere $\mathrm{sp} . \mathrm{B}$}

(P1. 3 fig. 15)

1989 Quadracythere sp. 1 Maybury MS; Fourniguet et al:: pl. 2, fig. 13.

?1991 Hermanites sp. B Cronin; pl. 8, fig. 3.

Diagnosis. Carapace elongate subovate in lateral view; anterior obliquely rounded and minutely denticulated. Dorsal convex, ventral sinuous. Reticulation characterized by a radial pattern of muri and fossae about a robust subcentral tubercle. Prominent anterodorsal ridge. Inclined $\mathrm{Y}$-structure of ridges and porecornuli developed posterodorsally, ventrolateral ridge terminates posteriorly in a bifurcate structure of nodes. Seven poreconuli arranged subconcentric mid-way between centre and margin in the dorsomedian and anterior fields. Two further pore-conuli located below mid height, behind subcentral tubercle.

Material. East Anglia, 4V.

Dimensions.

$\begin{array}{lllrr} & \text { Cat. No. } & \text { Site } & \text { Length } & \text { Height } \\ \text { ARV-F } & \text { AMW/PL/024 } & \text { OSC1/OR12 } & 0.75 & 0.39 \\ \text { ARV-M } & \text { AMW/PL/025 } & \text { OSC1/OR12 } & 0.74 & 0.37\end{array}$

Distribution. Pliocene; Coralline Crag Formation, Orford, Suffolk, UK; ?Mactra Zone, Tjörnes Iceland (Cronin, 1991). Remarks. In lateral view $T . s p$. B is clearly allied with $T$. hoptonensis (Brady et al., 1874) as both posses a very well developed, marginal, anterodorsal ridge; convex dorsal margin and pore-conuli in the dorsal field. However, $T$. hoptonensis differs in possessing muri with a subdued concentric component, being less elongate and lacking the complex, posterodorsal structure. $T$. vermiculata $\mathrm{sp}$. nov. also possess a strong dorsolateral ridge but unlike $T$. sp. B it possesses two characteristic sub-parallel, plicate, muri in the anteromedian region.

\section{ACKNOWLEDGEMENTS}

The authors extend their thanks to Dr Leendert Witte of the Dutch Geological Survey, Professor Brian Funnell and Dr Christopher Hunt for providing material for this study. Special thanks to Dr John Whittaker of the British Museum (Natural History) and Peter Davis of the Hancock Museum for access to type material.

\section{Manuscript received November 1993 Manuscript accepted May 1995}

\section{REFERENCES}

Athersuch, J., Horne, D. J. \& Whittaker, J. E. 1982. Coralline Crag Ostracoda. Proceedings of the Geologists' Association, 93: 313-316.

Athersuch, J., Horne, D. J. \& Whittaker, J. E. 1989. Marine and Brackish water ostracods (Superfamilies Cypridacea and Cytheracea): Keys and notes for the identification of the species. In Kermack, D. M. \& Barnes, R. S. K. (Eds), Synopses of the British Fauna (New Series), 43, 343 pp. 8 pls. Published for Linnean Society, London. Estuarine and Brackish-water Science Association, E. J. Brill, Leiden. Bassiouni, M. A. 1962. Ostracoden aus dem Mittelmiozän in NW Deutschland. Roemeriana, Clausthal-Zellerfellf, 3: 1-99, 9 pls.

Bassiouni, M. A. 1965. Ueber einige Ostracoden aus dem Interglazial von Esbjerg. Meddelelser fra Dansk geologisk Forening, 15: 507-518.

Bell, A. \& Bell, R. 1872. On the English Crags and the stratigraphic divisions indicated by their Invertebrate fauna. Proceedings of the Geologists' Association, 2: 185-218.

Bosquet, P. 1852. Description des Entomostraces fossilie des terrains tertaires de la France et de la Belgique. Mémoires de l'Académie r. des Sciences, des lettres et des beaux-arts de Belgiques, 24: 142 pp., 6 pls.

Brady, G. S. 1878. A monograph of the Ostracoda of the Antwerp Crag. Transactions of the Geological Society of London, 10: 379-409, pls 6269.

Brady, G. V., Crosskey, H. \& Robertson, D. 1874. A monograph of the Post-Tertiary Entomostracea of Scotland including species from England and Ireland. Palaeontographical Society (Monograph), 1874: $1-232$, pis $1-16$.

Brady, G. S. \& Norman, A. M. 1889. A monograph of the marine and freshwater Ostracoda of the North Atlantic and of Northwestern Europe. Section 1, Podocopa. Scientific Transactions of the Royal Dublin Society, ser. 2, 4: 63-270, pls 8-23.

Cronin, T. M. 1991. Late Neogene marine Ostracoda from Tjörnes, Iceland. Journal of Paleontology, 65: Chicago, 767-789.

Cronin, T. M., Briggs, W. M. Jr., Brouwers, E. M., Whatley, R. C., Wood, A. M. and Cotton, N. 1992. Modern Arctic ostracode database. US Geological Survey Professional Paper, 91-358, $51 \mathrm{pp}$.

Doppert, J. W. 1975. Foraminiferenzonering van het Nederlands OnderKwartair en Tertiair. In Zagwijn, W. H. \& Staalduinen, van C. J. (Eds), Toelichting bij de Geologische Overzichtskaarten van Nederland, 11-118. Rijks Geolodische Dienst, Haarlam.

Doppert, J. W. 1980. Lithostratigraphy and biostratigraphy of marine Neogene deposits in the Netherlands. Mededelingen van's Rijks geologischen Dienst, 32: 255-311.

Egger, J. G. 1858. Die Ostrakoden der Miocäne-Schichten bei Ortenburg in Nieder-Bayern. Neues Jahrbuch für mineralogie, Geologie und Paläontologie, 1858: 403 443, pls 14-19.

Elofson, O. 1941. Zur Kenntnis der marinen Ostracoden Schwedens mit besonderer Berucksichtigung des Skageraks. Zoologiska Bidrag fran Uppsala, 19: 217-534.

Faupel, M. 1975. Die Ostrakoden des Kasseler Meeressandes (Oberoligozän) in Nordhessen. Göttinger Arbeiten zur geologie und Paläontologie, 17: 77 pp., 13 pls.

Fourniguet, J., Trautmann, F., Margerel, J. P., Whatley, R. C., Maybury, C. \& Morzadec-Kerfourn, M. T. 1989. Les argiles et sables pliocènes de Saint-Jean-la-Poterie (Morbihan): Sédimentologie, micropaléontologie (foraminifères, ostracodes et palynologie). Géologie de la France, 1-2: 55-78, 3 pls.

Funnell, B. M. 1987. Late Pliocene and Early Pleistocene stages of East Anglia and the adjacent North Sea. Quaternary Newsletter, 52: 1-11.

Harmer, F. W. 1900. On a proposed new classification for the Pliocene deposits for the east of England. Report of the British Association for the Advancement of Science, 751-753.

Hazel, J. E. 1967. Classification and distribution of the Recent Hemicytheridae and Trachyleberididae (Ostracoda) off northeastern 
North America. US Geological Survey Professional Paper, Washington DC, 564, 1-49, 11 pls.

Hazel, J. E. 1968. Pleistocene Ostracoda Zoogeography in Atlantic coast Submarine Canyons. Journal of Paleontology, 42: 1264-1271.

Hazel, J. E. 1977. Distribution of some biostratigraphically diagnostic ostracodes in the Pliocene and lower Pleistocene of Virginia and northern North Carolina. Journal of US Geological Survey Research, 5: $373-388$

Horne, D. J. \& Kerr, P. 1989. Ostracods and foraminifera from the Pleistocene Knocknasillage Member, County Wexford, Ireland. Geological Journal, 24: 71-74, 2 pls.

Horne, D. J. \& Whittaker, J. E. 1983. On Baffinicythere howei Hazel. Stereo-Atlas of Ostracod Shells, 10: 53-62.

Jenkins, D. G. \& Houghton, S. D. 1987. Age, correlation and palaeoecology of the St. Erth Beds and the Coralline Crag of England. Mededelingen van de Werkgroep voor Tertiaire en Kwartaire Geologie, 24: 147-156.

Jones, T. 1857. A monograph of the Tertiary Entomostraca of England. Palaeontographical Society (Monograph), London, 9, 68 pp, 6 pls.

Jones, T. 1870. Notes on the Tertiary Entomostraca of England. Geological Magazine, London, 7, 155-159.

Jones, T. \& Sherborn, C. 1887. Further notes on the tertiary Entomostraca of England with special reference to those from the London Clay. Geological Magazine, London, 3(4-9) 385-393, 450460 , pl. 1.

Jones, T. \& Sherborn, C. 1889. A supplementary monograph on the Tertiary Entomostraca of England. Palaeontographical Society (Monograph), 69: 55 pp., 3 pls.

Keij, A. J. 1957. Eocene and Oligocene Ostracoda of Belgium. Mèmoires de l'Institut $r$. des Sciences naturelles de Belgiques, 136: 1-210, 23 pls.

Kuiper, W. N. 1918. Oligocäne und Miocäne Ostracoden aus den Niederlanden. Proefschr., University of Groningen, Groningen (Gebr. Hoitsema), 1-91, 3 pls.

Liebau, A. 1977. Carapace ornamentation of the Ostracoda Cytheracea: principles of evolution and functional significance. In Löffer, H. \& Danielopol, D. (Eds), Aspects of Ecology and Zoogeography of Recent and Fossil Ostracoda. 107-120, 2 pls. W. Junk, The Hague.

Liebau, A. 1978. Die Muskelfeld-Evolution der Trachyleberididae (Ostracoda). Neues Jahrbach für Geologie und Paläontologie Abhandlungen, 157: 123-128.

Liebau, A. 1982. Zoogeographie nordatlantischer und mediterraner Trachyleberididen s.l. (Ostracoda). Neues Jahrbach fïr Geologie und Paläontologie Abhandlungen, 164: 271-280.

Liebau, A. 1991. Skulptur-Evolution bei Ostrakoden am Beispiel europäischer 'Quadracytheren'. Geologische und paläontogische. Westf., 13: 395 pp., pls 1-95.

Lienenklaus, E. 1894. Monographie der Ostrakoden des nordwestdeutschen Tertiärs. Zeitschrift der Deutschen geologischen Gesellschaft, 46: $158-268$, pls $13-18$

Lord, A. R. 1980. Weichselian (Late Quaternary) ostracods from Sandnes Clay, Norway. Geological Magazine, London, 117(3): 227 242,3 pls

Lord, A. R., Horne, D. J. \& Robinson, J. E. 1988. An Introductionary Guide to the Neogene and Quaternary of East Anglia for Ostracod Workers. British Micropalaeontology Society Field Guide, 5, 10 pp.

Malkin, D. S. 1953. Biostratigraphic study of Miocene Ostracoda of New Jersey, Maryland, and Virginia. Journal of Paleontology, 27: 761799

Maybury, C. A. \& Whatley, R. C. 1980. The ostracod genus Leptocythere from the Pliocene deposits of St. Erth, south Cornwall and North-West France. Revista Española de Micropaleontologia, 12(3): $435-468,5$ pls.

Maybury, C. A. \& Whatley, R. C. 1986. A high diversity ostracod fauna of Late Pliocene age from St. Erth, south Cornwall. Proceedings of the Ussher Society, 6: 312-317.

Maybury, C. A. \& Whatley, R. C. 1988. The evolution of high diversity in the ostracod communities of the upper Pliocene faunas of St. Erth (Cornwall, England) and north west France. In Hanai, T., Ikeya, N. \& Ishizaki, K. (Eds) Evolutionary Biology of Ostracoda; its Fundamentals and Application, 11, 569-596. Devs Palaeont. Stratigr., Amsterdam.

Moos, B. 1963. Über einige der 'Cythere macropora' Bosquet 1852
(Ostr.) ähnliche Arten aus verschiedenen Tertiärstufen. Geologische Jahresberichle, 82: 21-42, 2 pls.

Norman, A. M. 1865. Deepsea dredging on the coasts of Northumberland and Durham, in 1864. In British Association for the Advancement of Science, Report, [34th meeting, Bath, 1864], Brady, G. S. (Ed.), 1865: 189-193.

Peypouquet, J. P. 1971. Inverntaire de la microfaune d'Ostracodes de la region de Cap-Breton. Bulletin de l'Institut de Geologie du Bassin d'Aquitaine, 11: 191-208.

Peypouquet, J. P. 1973. Sur la présence d'éspèces mediterran_ennes au niveau des étages circalittoral et épibathyal de la zone de Cap-Breton. Bulletin de l'Institut de Geologie du Bassin d'Aquitaine, 13: 143-146.

Reid, C. 1882. The geology of the country around Cromer. Memoirs of the British Geological Survey, London, $137 \mathrm{pp}$.

Reuss, A. E. 1850. Die fossilen Entomostraceen des Oesterreichischen Tertiörbeckens. Naturwisserischaftliche Abhandlungen, 3: 41-91.

Sars, G. O. 1866. Oversigt af Norges marine Ostracoder. Forhandlinger $i$ Videnskabsselskabet $i$ Kristiania, 7: 1-130.

Speyer, O. 1863. Die Ostracoden aus den Kasseler Tertiarbilungen. Bericht des Naturwissenschaftlichen Vereins, Cassel, 63 pp., 4 pls.

Tabuki, R. 1986. Plio-Pleistocene Ostracoda from the Tsugaru Basin, north Honshu, Japan. Bulletin of the College of Education, 29: 27-159.

Uffenorde, H. 1980. Uber die Ostracodenverteilung im Miozän des nördlichen Niederachsen (NW Deutschland). Neues Jahrbuch für Mineralogie, Geologie und Paläontologie. Manatshefte 5: 303-320.

Uffenorde, H. 1981. Ostracoden aus dem Oberoligozän und Miozän des unteren Elbe-Gebietes (Niedersachsen und Hamburg, NW-deutsches Tertiärbecken). Palaeontographica, A172: 103-198, 10 pls.

Uffenorde, H. 1986. Stratgraphical and palaeoecological aspects of Upper Oligocene and Miocene Ostracoda of Lower Saxony. In Tobien, H. (Coord.), Nordwestdeutschland im Tertiär. Beitrage zur Regionalen Geologie der Erde. Berlin 18: 422 436.

Uffenorde, H. 1990. Ostrakoden des Tertiär aus der Forschungsbohrung Wursterheide (NW-Deutschland): II. Höheres Mittel-Oligozän bis Ober-Miozän. Jahrbuch der Geolischen, A111: 367-401, 2 pis.

Wilkinson, I. P. 1980. Coralline Crag Ostracoda and their environmental and stratigraphical significance. Proceedings of the Geologists' Association, 91: 291--306.

Wilkinson, I. P, Wood, A. M. \& Maybury, C. A. in press. The Neogene. In Athersuch, J. Keen, M. C. \& Wilkinson, I. P. (Eds) The revised stratigraphical index of British Ostracoda. BMS publication, Chapman and Hall, London.

Wood, A. M. \& Whatley, R. C. in press. New Ostracod Based Biostratigraphy for the Pliocene Marine Succession of The Netherlands. 2nd European Ostracologists Meeting, Glasgow.

Wood, A. M. \& Whatley, R. C., 1994. Northeastern Atlantic and Arctic faunal Provinces based on the distribution of Recent ostracod genera. The Holocene, 4: 174-192

Wood, A. M., Whatley, R. C., Cronin, T. M.\& Holtz, T. 1994. Pliocene palaeotemperature reconstruction of the southern North Sea based on Ostracoda. Quaternary Science Reviews, 12, 747-767.

Wood, A. M., Whatley, R. C., Maybury, C. A. \& Wilkinson, I. P. 1992. Three new species of Cytheracean Ostracoda from the Coralline Crag at Orford, Suffolk. Journal of Micropalaeontology, 11, 211-220

Wood, S. V. 1848-1882. The Crag Mollusca. Palaeontological Society (Monograph), London, 2 volumes and 3 supplements.

Wouters, K. 1973. Le genre Aurila Pokorny (Crust., Ostr.) dans le PlioPliéstocène de Belgique. Revue de Micropaleontologie, 16: 194-201.

Wouters, K. 1976. Cushmanidea lithomoides (Bosquet, 1852) C. elongata (Brady, 1868): A case of phyletic evolution from the Oligocene to Recent in N.W. Europe (Crustacea: Ostracoda). Bulletin de la Société belge de géologie de paléontologie et d'hydrologie, 85: 107-115.

Wouters, K. 1979. On the taxonomy and distribution of some European species of the genus Muellerina Bassiouni, 1965. In Proceedings of the VIl International Symposium on Ostracodes, Belgrade, 1978. Taxonomy, Biostratigraphy and Distribution of Ostracodes, Serbian Geological Society, Belgrade. pp. 223-232, 2 pls.

Yassini, 1. 1969. Ecologie des Associtions d'Ostrcodes du Bassin d'Arcachon et du littoral Atlantique. Application-l'interpretation de quelques populations du Tertiaire Aquitain. Bulletin de l'Institut de Géologie du Bassin d'Aquitaine, 7: 1-288, pls 1--39. 